\title{
Evolution of the danube deep-sea fan since the last glacial maximum: New insights into Black Sea water-level fluctuations
}

\author{
Constantinescu Adriana ${ }^{1,2,{ }^{*}}$, Toucanne Samuel ${ }^{2}$, Dennielou Bernard ${ }^{2}$, Jorry Stephan ${ }^{2}$, Mulder T. ${ }^{3}$, \\ Lericolais Gilles ${ }^{2}$
}

${ }_{1}^{1}$ Natl Inst Marine Geol \& GeoEcol GeoEcoMar, RO-024053 Bucharest, Romania.

2 IFREMER, Lab Environm Sedimentaires, F-29280 Plouzane, France.

3 Univ Bordeaux, UMR CNRS EPOC 5805, F-33615 Pessac, France.

* Corresponding author : A. M. Constantinescu, email address : adriana.c@geoecomar.ro

\begin{abstract}
:
The Danube Deep-Sea Fan (NW Black Sea) is one of the most developed deep-sea sediment depositional systems in Europe. Although the morphology and the architecture have been widely described in the past years, little is known about the stratigraphy of this depositional system. For the late Quaternary, this results from the lack of significant stratigraphic markers, the scarcity of radiocarbon ages and the difficulty in constraining reservoir ages. Recent robust quantification of reservoir ages has allowed the construction of a new stratigraphic framework for the Black Sea from the end of the last glacial period to the Holocene, thus giving the opportunity to correlate sedimentological and geochemical features previously described on the NW Black Sea margin with climatic events identified in the Northern Hemisphere. Based on this approach, we propose an improved chrono-lithostratigraphic framework for the Danube Deep-Sea Fan channel-levees since the Last Glacial Maximum. We show that the Danube Deep-Sea Fan was active during the Last Glacial Maximum until the Younger Dryas-Early Holocene transition ca. 11,700 cal a. BP, when the turbidite activity abruptly terminated in the whole system. Throughout this period, the Danube River was the main source of the deep depositional system, except between ca. 17,200 cal a. BP and 15,700 $\pm 300 \mathrm{cal} \mathrm{a}$. BP. At that time, the deposition of 'red turbidites' in the deep basin, concomitant with the deposition of the so-called 'Red Layers' onto the continental shelf and the upper slope, emphasises the direct impact of the increased meltwater runoff of the Dnieper River as far as the Danube Deep-Sea Fan. Some significant changes in the location of the depocentre of the Danube Deep-Sea Fan occurred through time. The main change in depocentre location occurred at ca. $28,000 \mathrm{cal}$ a. BP, with the northward avulsion leading to the formation of the Middle Channel. Although the Middle and Northern Channel became the preferential turbidite depocentres after this event, the deposition of turbidites has persisted in the Southern channel-levee until $14,700 \mathrm{cal}$ a. BP, indicating that the Southern Channel was definitely not abandoned after the upstream northward avulsion. Unsurprisingly, water-level fluctuations and river sediment flux acted as the main forcings on the evolution of the Danube Deep-Sea Fan. Based on these results, and on the morphology of the Danube Canyon,
\end{abstract}


we propose that (i) lowstand conditions $(\leq-110 \mathrm{~m}$ ) prevailed during the Last Glacial Maximum, and possibly between $15,700 \pm 300 \mathrm{cal} \mathrm{a}$. BP and $14,700 \mathrm{cal} \mathrm{a}$. BP, (ii) water-level ranged from $\geq-110$ and $\leq-70 \mathrm{~m}$ between 14,700 and $11,700 \mathrm{cal} \mathrm{a}$. BP, and (iii) water-level ranged from $\geq-70$ and $\leq-30 \mathrm{~m}$ from $11,700 \mathrm{cal}$ a. BP and until the reconnection of the Black Sea 'Lake' with the global ocean at ca. 9000 cal a. BP.

\section{Highlights}

We propose the first high-resolution stratigraphic framework for the Danube Deep-Sea Fan. Significant shifts in the location of turbidite depocenter since the Last Glacial Maximum $>$ The turbidite activity in the Danube Deep-Sea Fan abruptly stopped ca. 11,700 yr BP. Our results give new insights into Black Sea water-level fluctuations.

Keywords : Danube deep-sea fan, Turbidites, Stratigraphy, Last glacial maximum, Termination 1, Waterlevel fluctuations 


\section{INTRODUCTION}

The Black Sea has undergone alternating phases of lacustrine and marine environment over geological timescales directly related to its semi-enclosed character and to eustatic sea-level oscillations. During lowstand conditions, the Black Sea was a giant lake disconnected from the global ocean, while during highstand conditions (as today), it was a marine basin communicating with the Mediterranean Sea through the Bosphorus and Dardanelle straits (e.g. Ross et al., 1970).

The Danube Deep-Sea Fan (NW Black Sea) was fed during lowstand periods by the Danube River, and is one of the most developed deep-sea sediment depositional system in Europe (Wong et al., 1994; Winguth et al., 2000) (Figures 1, 2 and 3). Until recently, the morphology and architecture of this turbidite system was largely unknown. Recent works brought new insights rising important questions regarding the age of the system and the internal and external forcing factors controlling its growth (Popescu et al., 2001, 2004; Popescu, 2002, Lericolais et al., 2013). Several sedimentary cores were used to discuss the recent evolution of the Danube Deep-Sea Fan (Popescu et al., 2001; Popescu, 2002; Lericolais et al., 2013), but the lack of significant stratigraphic markers, the scarcity of radiocarbon ages and the difficulty in constraining reservoir ages (i.e. the difference between the radiocarbon age of the water body and the contemporary atmosphere; e.g. Jones and Gagnon, 1994; Ryan, 2007; Kwiecien et al., 2008) have prevented such reconstruction at a millennial time-scale. Recently, Soulet et al. (2011a; 2011b) proposed a new stratigraphic framework for the Black Sea 'Lake' from the end of the last glacial period to the subsequent glacial-interglacial transition (i.e. Termination 1, between ca. 20,000-10,000 calendar years Before Present -1950 AD-, expressed as cal a. BP thereafter) based on a high-resolution quantitative reservoir age record (Figure 4). This robust quantification of reservoir ages differs from those previously published (Ryan, 2007; 
Kwiecien et al., 2008) since it is the first to be based on the tuning of a meaningful highresolution Black Sea surface temperature (through GDGT thermometer TEX $_{86}$ obtained from core MD04-2790; Figure 2) to a climate reference record (i.e. Hulu Cave $\nabla^{18} \mathrm{O}$ record). This allowed the assignment of a precise stratigraphic framework to sedimentological and geochemical features previously described on sediment cores retrieved from the continental slope (Major et al., 2002, 2006; Bahr et al., 2005, 2006, 2008; Kwiecien et al., 2008) and thus correlating them with the climatic events identified in the Northern Hemisphere (Figure 4).

Based on these recent findings, the aim of this study is to propose an improved chronolithostratigraphic framework for the Danube Deep-Sea Fan channel-levees since the Last Glacial Maximum (ca. 26,000-19,000 cal a. BP; Clark et al., 2009). This allows for the first time the documentation of the recent functioning of the Danube Deep-Sea Fan and its associated channel-levee systems, and the discussion of its evolution in response to climate change, river runoff and water-level fluctuations.

\section{REGIONAL CONTEXT}

\subsection{Geological setting}

The Black Sea is a semi-enclosed basin of $432,000 \mathrm{~km}^{2}$ and the largest anoxic basin in the world. It communicates with the global ocean through Bosphorus and Dardanelle straits (Figure 1). The opening of the Black Sea took place in a back-arc geodynamic regime, during Cenomanian to Coniacian times (Upper Cretaceous), associated with the northward subduction of the Thetyan Plate (Robinson, 1997). The Black Sea is divided into two basins separated by the Andrusov Ridge and shows a thick sedimentary cover of ca. $11 \mathrm{~km}$ and 19 $\mathrm{km}$ in the eastern and western basin, respectively (Nikishin et al., 2003). Since the Pliocene a 
rapid subsidence of the basin due to down-bending of the lithosphere in compression conditions have allowed the deposition of a $2.5-3 \mathrm{~km}$ thick unit, mostly represented by clayey sediments (Nikishin et al., 2003). This unit results mainly from the sediment supply from Central Europe via the Danube River and from Eastern European rivers, i.e. the Dnieper, Dniester and Southern Bug. The sediment inflow contributed to the shaping of the NW Black Sea margin from the coastal area, marked by deltaic deposits, down to the deep basin where large deep-sea fan complexes including the Danube Deep-Sea Fan were formed (Wong et al., 1994; Wong et al. 1997; Popescu, 2002; Lericolais et al. 2013).

\subsection{The Danube Deep-Sea Fan}

The continental slope of the NW Black Sea margin is truncated by numerous canyons, which frequently stop at the shelf-break (-170 to $-140 \mathrm{~m}$ water depth) with the exception of the Danube Canyon, which deeply incises the shelf for $26 \mathrm{~km}$ landward to $-110 \mathrm{~m}$ water depth (Figure 2). The Danube Canyon acted as a major gateway for the sediment transfer towards the deep Black Sea and the Danube Deep-Sea Fan (Popescu et al., 2004). The Danube DeepSea Fan is defined as a fine-grained turbidite system that extends for about $150 \mathrm{~km}$ downslope of the shelf-break and reaches the abyssal plain at $2200 \mathrm{~m}$ water depth (Popescu et al., 2001) (Figure 2). Wong et al. (1994) and Winguth et al. (2000) identified eight seismic units in the Danube Deep-Sea Fan, consisting of typical channel-levee turbidite facies and mass transport deposits settled during lowstand (i.e. lacustrine) conditions and condensed hemipelagic layers deposited during highstands (i.e. marine conditions). This suggests that the water-level fluctuations and the quality of the river-canyon connection are crucial parameters controlling the input to the Danube Deep-Sea Fan. Based on this conceptual scheme, Winguth et al. (2000) assigned an age of ca. 900,000 yr for the initiation of the fan. 
The recent acquisitions of high-resolution bathymetry, acoustic imagery and seismic profiles reveal that the uppermost channel-levee complex (i.e. sequence 8 of Winguth et al., 2000, that corresponds to the Northern, Middle and Southern channel-levee systems indicated in Figures 2 and 3) is composed of seven channel-levee systems (Winguth et al., 2000; Lericolais et al., 2013). This pattern indicates significant avulsions through time (i.e. breaching of sedimentary levees and formation of a new channel-levee system; see Kolla et al., 2007, for a thorough review), with a northward shift, as shown by Popescu (2002) (Figure 3). The age of the last channel-levee complex, as well as of each of the seven channel-levee systems, is still a matter of debate. Although Winguth et al. (2000) and Lericolais et al. (2013) proposed that the last channel-levee complex formed during the last glacial lowstand or Neoeuxinian period, equivalent to Marine Isotope Stage (MIS) 4-2 (ca. 74,000-14,000 cal a. BP, also termed the Post Karangatian-Neoeuxinian period; Chepalyga, 1985), Popescu (2002) challenged this interpretation, claiming that the northwards avulsions are not limited to this period.

2.3. Climate and water-level fluctuations in the Black Sea during the last 30,000 years

The modern hydrology of the Black Sea is strongly governed by the discharge of major Eurasian rivers (the Danube, Dniester and Dnieper) and by the water exchanges with the Mediterranean Sea through the shallow Bosphorus Strait ( $\sim 35$ metres below sea level, mbsl). The waters are currently stratified with a near-surface layer of salinity of ca. 18 PSU down to 90/120 m and a salinity of ca. 22.5 PSU of Mediterranean origin below. The connection with the Mediterranean Sea has been interrupted repeatedly over the last $\sim 3$ million years (Deuser, 1972), causing the Black Sea to oscillate between lacustrine and marine conditions twelve times during the last 670,000 years (Badertscher et al., 2011). During eustatic lowstand conditions (ca. $-120 \mathrm{~m}$ ) corresponding to Northern Hemisphere glaciations, the Black Sea was 
a giant lake, as demonstrated for each of the last glacial intervals as early as MIS 12 (ca. 400 ka BP) at least (Badertscher et al., 2011), including MIS 6 (ca. 190-130 ka BP, or the PostUzunlar period; Shumilovskikh et al., 2013; Wewgerth et al., 2014) and MIS 4-2 (Ross et al., 1970; Degens and Ross, 1972; Major et al., 2006; Shumilovskikh et al., 2014 among others). Both the age and mode of reconnections between the Black Sea 'Lake' and the Mediterranean Sea during glacial-interglacial transitions are still a matter of debate.

For the last glacial-interglacial transition (Termination 1), the 'catastrophic' hypothesis of Ryan et al. (1997; 2003) argued that the Mediterranean Sea rose to the Bosphorus sill at around 7,150 cal a. BP and filled the Black Sea 'Lake' with marine water in just a few years. On the contrary, many other authors advocated a non-catastrophic (i.e. gradual) reconnection (Aksu et al., 2002; Hiscott et al., 2007a, 2007b; Nicholas et al., 2011; Yanko-Hombach et al., 2007, 2014). Aksu et al. (2002) propose a unidirectional flow of the Black Sea freshwater into the Mediterranean Sea occurred at around 9,500 cal a. BP, which delayed the marine invasion of the Black Sea 'Lake' by 2000 years, at around 7,600 cal a. BP. Soulet et al. (2011b) recently constrained the last reconnection at 9,000 cal a. BP (9,300 cal a. BP for Bahr et al., 2008) with a gradual mode, showing that the level of the isolated Black Sea was below the former Bosphorus sill depth at the time of the last reconnection. These constraints for the Initial Marine Inflow (IMI) in the Black Sea $(8,995 \pm 145$ cal a. BP) and the Disappearance of Lacustrine Species (DLS; $8080 \pm 250 \mathrm{cal}$ a. BP) indicates, as do previous studies (Major et al., 2006; Ryan, 2007), that approximately ten centuries were needed to establish the currently observed two-way flow exchange with the Mediterranean Sea. These recent chronological constraints for the last reconnection also allowed the review of the chrono-stratigraphy of the well-known sedimentary sequences of Degens and Ross (1972) (i.e. the so-called Unit I, II and III) that indicate the change from lacustrine (Unit III, banded lutite, deposited before 8080 $\pm 250 \mathrm{cal}$ a. BP according to Soulet et al., 2011b) to marine conditions (Unit II, sapropel, until 
$2720 \pm 160$ cal a. BP according to Jones and Gagnon, 1994, overlaid by Unit I, microlaminated coccolith ooze).

Water-level fluctuations of the Black Sea 'Lake' have also been reconstructed for the last glacial episode. However, the results are still equivocal. At that time, the water level was controlled by regional climate and varied independently from global sea level (Ross et al., 1970). Based on seismic stratigraphy (Ryan et al., 1997; Winguth et al., 2000; Aksu et al., 2002; Lericolais et al., 2009, 2010, 2011) and reservoir age reconstructions (Soulet et al., 2011a), it is suggested that the water level of the Black Sea 'Lake' oscillated from ca -150/$100 \mathrm{~m}$ (e.g. during the LGM) to ca. $-35 /-25 \mathrm{~m}$, that corresponds to the depth of the Bosphorus sill. However, recent geochemical analyses in the Marmara Sea suggest that overspill of Black Sea water through the Bosphorus sill was continuous from ca. 75-50 cal a. BP to ca. 15 cal a. BP (Aloisi et al., 2015). This indicates by extension that the water level over this interval was ca. $-30 \mathrm{~m}$. In contrast, recent studies focusing on the last ca. $30 \mathrm{ka}$ demonstrate that such a water level was reached only after the Black Sea Meltwater Pulses (Soulet et al., 2011a, 2013). The latter interval, recorded in the Black Sea sediments as the so-called 'Red Layers' (Major et al., 2002; Ryan et al., 2003; Bahr et al., 2005; Soulet et al., 2011a), corresponds to the abrupt drainage of the Fennoscandian ice sheet into the Black Sea by the Dnieper River during Termination 1. The source for this event has been recently constrained through radiogenic isotopes (Soulet et al., 2013). This event estimated first between around $18,000 \mathrm{cal}$ a. BP (i.e. coeval with the onset of Termination 1; Pirazzoli, 1996) and 14,500 cal a. BP (i.e. coeval with the global Meltwater Pulse 1A; Lericolais et al., 2009) was precisely dated between ca.17,200 and 15,700 $\pm 300 \mathrm{cal}$ a. BP by Soulet et al. (2011a). The contribution of the Danube River, through its connection with the Alpine ice-sheet, is expected to be much less than that of the Dnieper River but no quantification exists for that time. Following the Younger Dryas cold event ( 12,650-11,700 cal a. BP), Lericolais et al. (2007, 2009, 2010, 
2011) suggest a new significant lowering down to $-100 \mathrm{~m}$, based on the occurrence of aerial coastal dunes still visible on the Romanian shelf under the post-glacial marine mud drape. However, no evidence of such a lowstand interval is found in the southwestern Black Sea (Aksu et al., 2002) for example, making this assumption controversial (e.g. Giosan et al., 2009; Mudie et al., 2014; Yanko-Hombach et al., 2014).

As shown through the Black Sea Meltwater Pulses, the water-level in the Black Sea 'Lake' fluctuated independently of global sea level, thus indicating the primary role of climate change (i.e. evaporation versus runoff) on past water-level fluctuations. Recent results have revealed that stable climate conditions prevailed during the LGM, with an average temperature of $5^{\circ} \mathrm{C}$, followed by an abrupt warming of $10^{\circ} \mathrm{C}$ during Termination 1 (including the Bølling-Allerød Interstadial period, 14,700-12,650 cal a. BP), interrupted by a cooling of 5- $6^{\circ} \mathrm{C}$ during the Younger Dryas (Ménot and Bard, 2012). These climatic conditions caused high surface runoff of the Danube and East European Rivers during the LGM and Termination 1, followed by a gradual decrease of the runoff to the present-day conditions (Sidorchuk et al., 2008, 2011; Kasse et al., 2010).

Here we focus on the Danube Deep-Sea Fan to explore the impact of these palaeoenvironmental changes on its evolution since the LGM.

\section{MATERIAL AND METHODS}

This study is based on seven Kullenberg piston cores collected on the NW Black Sea margin during the BLASON (1998) and BLASON 2 (2002) oceanographic cruises onboard R/V 'Le Suroit' (IFREMER). The cores are located along the Danube Canyon (core BLKS98-27 at 651 metres water depth, mwd) and in the Danube Deep-Sea Fan (cores BLKS98-22, BLKS98-23, B2KS-31, BLKS98-24 and BLKS98-25 from 2100 to $1762 \mathrm{mwd}$ ). Core BLKS98-27 is sited 
on a terrace ca. $230 \mathrm{~m}$ above the Danube Canyon, while cores BLKS98-22, BLKS98-23, B2KS-31, BLKS98-24 and BLKS98-25 are located on sedimentary levees in the distal part of the turbidite system. The turbidite channel, adjacent to the levees, is ca 10-30 metres deep. Details about the cores and coring sites are given in Table 1 and Figure 2.

\subsection{Sedimentological analysis}

The sedimentological analyses of cores BLKS98-22, BLKS98-23, BLKS98-24, BLKS98-25, BLKS98-27 and B2KS-31 consist firstly of visual description and radiography (SCOPIX system; Migeon et al., 1999), which allowed the recognition of lithofacies (Figure 5). Spectrophotometric acquisition $\left(\mathrm{L}^{*}, \mathrm{a}^{*}, \mathrm{~b}^{*}\right)$ was automated with a GEOTEK Multi-Sensor Core Logger system and measurements were performed at $1 \mathrm{~cm}$ intervals with a Konica Minolta CM2600d (specular component excluded; D65 illuminant; $10^{\circ}$ observer; measurement area of $8 \mathrm{~mm}$; Debret et al., 2011). Spectrophotometric results presented in this study focus on the $a^{*}$ parameter, that measures the red-green chromaticity values [a* values range from -60 (green) to +60 (red)], for the recognition of the 'Red Layers' especially. Grainsize analyses were performed on bulk sediment samples at the University of Brest (IUEM) with a Malvern Mastersizer 2000 laser diffraction particle size analyser. Finally, smear slides observations were realised (not shown) and some sediment samples were analysed with a scanning electron microscope in order to characterise the sediment composition (i.e. chemical composition, mineralogy, microfossils; Figure 6). 


\subsection{X-ray fluorescence (XRF) analysis}

XRF scanner data allowed a detailed correlation between cores, preliminary stratigraphic interpretations and recognition of sedimentological events (e.g. turbidites, sapropels) (Croudrace et al., 2006; Richter et al., 2006). Previous studies reported good results for the analysis of sedimentary cores retrieved in deep-sea turbidite systems (Rothwell et al., 2006; Wien et al., 2007). As a result, the bulk intensity of major elements for cores BLKS98-22, BLKS98-23, BLKS98-24, BLKS98-25, BLKS98-27 and B2KS-31 was analysed using an Avaatech XRF core scanner (Rhodium source). XRF data were collected every $1 \mathrm{~cm}$ along the entire length of the cores, with a count time of 10 seconds, by setting the voltage to $10 \mathrm{kV}$ (no filter) and $30 \mathrm{kV}$ (Pd thick filter) and the intensity to $600 \mu \mathrm{A}$ and $1000 \mu \mathrm{A}$, respectively. In addition, some intervals (see Figures 7, 8, 9, 10 and 11) were analysed every $1 \mathrm{~mm}$ (count time of 30 seconds, voltage of $10 \mathrm{kV}$, and intensity of $1000 \mu \mathrm{A})$. This study is mainly concentrated on Titanium (Ti), Iron (Fe) and Calcium (Ca). It is commonly admitted that Ti and $\mathrm{Fe}$ are related to terrigenous-siliciclastic minerals (clays, heavy minerals), while $\mathrm{Ca}$ mainly reflects the carbonate content (calcite and aragonite) in the sediment (Richter et al., 2006). Following Rothwell et al. (2006), the authors also focused on the ratio between Zirconium $(\mathrm{Zr})$ and Rubidium $(\mathrm{Rb})$ to highlight the presence of turbidite deposits in the cores (Figures 8, 9, 10 and 11). Note that to account for the effect of lithology (e.g. density, porosity) or sediment surface irregularities on the XRF intensity values, we have normalized the raw total counts of a given element (e.g. Ca element in Figure 7) to the total counts of all processed elements for this measurement position $\left(\mathrm{Ca}_{\text {norm}}\right.$; see Bahr et al., 2014 for details about this normalisation). 


\section{RESULTS}

\subsection{Lithofacies}

The detailed analysis of cores BLKS98-22, BLKS98-23, B2KS-31, BLKS98-24, BLKS98-25 and BLKS98-27 permitted for the identification of 6 lithofacies based on sedimentary structures and composition (Figure 5).

Lithofacies 1: Microlaminated Coccolith Ooze (MCO)

This lithofacies is characterised by millimetre-scale grey and white laminae (Figures 5 and 7). XRF scanner analysis reveals relative high Ca intensity (Figures 7 and 12). Scanning electron microscope observations corroborate this result by showing abundant coccolithophores (Emiliania huxleyi; J. Giraudeau, personal communication; Figure 6). This facies is observed at the top of the 7 cores as a ca. $10 \mathrm{~cm}$ thick layer (Figures 7, 12 and 13; Table 2). Based on these observations, it is assumed that lithofacies 1 corresponds to Unit I of Degens and Ross (1972), consisting of alternating white, carbonate-rich, grey laminae produced by the fall-out of summer-fall coccolithophores blooms and winter-spring clastic sedimentation according to Hay (1988) and Pilskaln and Pike (2001).

\section{Lithofacies 2: Sapropel}

This lithofacies is characterised by a black-brown micro-laminated, jelly-like, organic-rich mud (Figures 5 and 7). XRF scanner analysis reveals relative very low $\mathrm{Ca}$ intensity, and relative high $\mathrm{Ti} / \mathrm{Ca}$ ratio (Figures 7 and 12) indicating that non-carbonated detrital material is dominant. Even though the carbon content is unknown, this lithofacies is interpreted as a sapropel layer. It is observed in all cores as a unique $20-30 \mathrm{~cm}$ thick layer at ca. $10 \mathrm{~cm}$ depth 
(Figures 5, 7, 12 and 13; Table 2). Based on these observations, this lithofacies 2 is interpreted as similar to Unit II of Degens and Ross (1972). The base of Unit II is dated at $8080 \pm 250 \mathrm{cal}$ a. BP (Soulet et al., 2011b). This date corresponds to the disappearance of lacustrine species (DLS) and the onset of strictly marine conditions in the Black Sea (Ryan et al., 1997; Major et al., 2002; Ryan et al., 2003).

\section{Lithofacies 3: Transitional olive mud}

This lithofacies is characterised by structureless olive-grey mud (Figures 5 and 7). XRF scanner analysis reveals relative low $\mathrm{Ca}$ intensities and a significant peak in $\mathrm{Ti} / \mathrm{Ca}$ ratio (Figures 7 and 12) suggesting the prevalence of the detrital sedimentation over carbonate precipitation (Bahr et al., 2005). This facies occurs in all cores as $2 \mathrm{~cm}$ to $8 \mathrm{~cm}$ thick strata (Figures 5, 7, 12 and 13; Table 2). Based on these observations and on previous work (Major et al., 2002, 2006; Bahr et al., 2005; Soulet et al., 2011b), lithofacies 3 is considered as a deposit that preceded the deposition of Unit II of Degens and Ross (1972). It is interpreted as the late Quaternary Initial Marine Inflow (IMI) in the Black Sea, i.e. the transition from a fresh/brackish to a marine environment (Ryan et al., 2003; Soulet et al., 2011b).

Lithofacies 4: Carbonate-rich silty clay

This lithofacies is characterised by dark-light grey slightly laminated silty clay (Figures 5 and 7), with distinct black spots or streaks of iron sulphides. XRF scanner analysis reveals very high XRF Ca intensity (in cores BLKS98-22 and BLKS98-24 especially; Figure 12) that is consistent with the observation of a high content of carbonates on smear slides (not shown) and by $\mathrm{CaCO}_{3}$ values ranging from $38 \%$ to $45 \%$ in core BLKS98-22 (see Strechie-Sliwinski, 2007, page 68). This facies is found in all cores, as a $6 \mathrm{~cm}$ to $60 \mathrm{~cm}$ thick layer. Based on 
these observations, it is interpreted as the upper part of the 'lacustrine' Unit III of Dean and Arthur (2011).

\section{Lithofacies 5: Red Layers}

This lithofacies comprises an alternation of homogenous red, grey-reddish or grey silty clay to clayey silt beds (Figures 5, 8 and 9). For the red to reddish beds, XRF analysis revealed high Ti/Ca ratio in cores BLKS98-22, BLKS98-23, BLKS98-24 and B2KS-31 (Figure 12). The radiography shows low intensities indicative of high density (Figure 5). The a* parameter is positive, between 4-6, and indicative of a colour spectrum that is dominantly red. The base of each red to reddish bed is often characterised by silt/sandy silt laminae (cores BLKS98-22, BLKS98-23, B2KS-31), and is interpreted here as turbidite (see lithofacies 6 below). It is referred to as 'red turbidites'. This interpretation is supported by millimetre-scale grain-size analysis (Figures 8 and 9). 5 'red turbidites' have been identified in core BLKS98-22, 14 in core BLKS98-23 and BLKS98-24 and about 40 in core B2KS-31.

This lithofacies corresponds to thick intervals found only in cores BLKS98-22 (52 cm-thick), BLKS98-23 (132 cm-thick), BLKS98-24 (85 cm-thick) and B2KS-31 (250 cm-thick) (Figures 12 and 13; Table 2). On the basis of these observations, this lithofacies is considered to represent the distal signature of the so-called 'Red Layers' previously described on the continental slope of the western Black Sea (Major et al., 2002; Ryan et al., 2003; Bahr et al., 2005; Soulet et al., 2011a).

\section{Lithofacies 6: Turbidites}

This lithofacies consists of a few millimetre to $10 \mathrm{~cm}$ thick grey sand or silt beds overlain by structureless grey and beige laminated clay (Figures 5, 8, 9, 10 and 11). Laminations are well outlined on X-ray radiographs by alternation of dark grey (denser) in the coarse layers and 
light grey (less dense) in the fine layers (Figures 8, 9, 10 and 11). XRF analysis has revealed high $\mathrm{Ca}$ and $\mathrm{Ca} / \mathrm{Fe}$ counts as well as high $\mathrm{Zr} / \mathrm{Rb}$ ratio in the coarser layers. A grain-size normal grading is observed, even in the fine silt layers, and is further outlined by the $\mathrm{Zr} / \mathrm{Rb}$ ratio that can be used as a qualitative proxy for grain-size fluctuations (Croudace et al., 2006; Rothwell et al., 2006). The upper stratum is dominated by clay-sized sediment (median around $5 \mu \mathrm{m}$ ), low $\mathrm{Ca}$ counts and $\mathrm{Zr} / \mathrm{Rb}$ ratio. The basal sand and silt layers have a sharp basal contact, rarely erosional (Figures 8, 9, 10). In some cases, they display horizontal laminations (rarely oblique-cross laminations) consisting of alternating silt and silty-clay. According to the classification of Stow and Piper (1984), this lithofacies is interpreted as finegrained base cut-out turbidites ( $T d-T e$ terms of the Bouma sequence) deposited from the overflow of turbidity currents through spillover processes.

The characteristics of turbiditic lithofacies (grain-size, colour, composition) do not always allow differentiation between the laminated facies produced by the alternation of single turbidites, or by the alternation of 'sweep and burst events' into the turbulent boundary layer of a single flow (Hesse and Chough, 1980; Shanmugam et al., 1993). The thin, centimetrescale, turbidites described in core B2KS-31 (Figure 9) and BLKS98-22 (Figure 10), show the same fluctuations in the composition as the thick turbidites described in core BLKS98-23 (Figure 8), suggesting that they correspond to the alternation of single turbidites and that the thin interval under the coarse laminae corresponds to the hemipelagic interval developed during the quiescence phase between two turbiditic events. This highlights the preservation of a continuous record of the turbidite activity. In addition, the thinness of the pelagic interval outlines the shortness of the quiescence between two turbidites, which is further confirmed by the high turbiditic accumulation rate (i.e. turbidite frequency) calculated in the cores (Figure 14). 


\subsection{Chronostratigraphic framework}

The chronostratigraphic framework of BLKS98-22, B2KS-31, BLKS98-24, BLKS98-25, BLKS98-27 and BLKS98-23 sequences is mainly based on XRF-Ca content and XRF-Ti/Ca ratio (Figures 7 and 12), since it has been demonstrated that biogenic, authigenic $(\mathrm{Ca})$ and detrital (Ti) inputs in the Black Sea fluctuated with regard to environmental changes (Degens and Ross, 1972; Bahr et al., 2005; 2006; Soulet et al., 2011a, 2013) (Figure 4). The environmental signature of the $\mathrm{Ti} / \mathrm{Ca}$ ratio in channel-levee systems could be biased by turbidite deposits since $\mathrm{Ti}$ is abundant at the base of turbidites (presence of heavy resistate minerals; Rothwell et al., 2006). As a result, the chronostratigraphic framework is also based on visual description (e.g. for recognition of the sapropel deposits) and on the spectrophotometric a* parameter (i.e. for the Red Layers in particular).

$\mathrm{XRF}$ analysis reveals prominent peaks in $\mathrm{Ca}$ intensity in the records, including a major $\mathrm{Ca}$ peak at the top of each of the studied cores (Figures 7 and 12). This feature is visible both along the Danube Canyon (core BLKS98-27) and in the Danube Deep-Sea Fan (cores BLKS98-23, BLKS98-24, BLKS98-25 and B2KS-31), demonstrating the ubiquitous nature of these carbonate-rich deposits. This assumption is supported by carbonate and XRF-Ca analyses collected on the upper slope of the NW Black Sea by Major et al. (2002; core BLKS98-10), Bahr et al. (2005, 2006, 2008; core GeoB 7806-1), Kwiecien et al. (2008; composite core MD04-2788/2760) and Soulet et al. (2011a; core MD04-2790) (Figure 2) that show a similar pattern for variations in the $\mathrm{Ca}$ content (Figure 4). Consequently, the uppermost $\mathrm{Ca}$ peak associated to the microlaminated coccolith ooze (Facies 1, MCO) is correlated here to Unit I of Degens and Ross (1972) (Figures 7, 12 and 13; Table 2). The base of Unit I, defined as the first appearance of E. huxleyi in the Black Sea during the Holocene (i.e. first white laminae in the upper part of sedimentary cores; see Dean and Arthur, 2011, for 
details) is dated at $2720 \pm 160 \mathrm{cal}$ a. BP according to Jones and Gagnon (1994). Similarly, the oldest peaks in $\mathrm{Ca}$ intensity corresponding to the carbonate-rich silty-clay, described as lithofacies 4, were correlated to those recognised on the continental slope (Figure 4). These Ca-rich intervals correspond to the upper part of the 'lacustrine' Unit III were deposited between 14,700 and $8,995 \pm 145 \mathrm{cal}$ a. BP, according to the recent chronology of Soulet et al. (2011a). In detail, the two peaks in $\mathrm{Ca}$ intensity (named $\mathrm{C} 2$ and $\mathrm{C} 1$ ) identified in this lacustrine unit coincide with the Bølling-Allerød Interstadial (14,700-12,650 cal a. BP) and the Early Holocene $(11,700-8,995 \pm 145$ cal a. BP) periods, respectively (Soulet et al., 2011a) (Figures 12 and 13). The decrease in the Ca intensity observed between these episodes, and corresponding to a slight increase in the $\mathrm{Ti} / \mathrm{Ca}$ ratio, is correlated to the Younger Dryas cold event (12,650-11,700 cal a. BP, named Glacial-Type 1 -GT1- in Figure 4, 7, 12 and 13; see Soulet et al., 2011a, for details).

Previous cold episodes described from Central Europe (Ménot and Bard, 2012), including the LGM and the Heinrich Stadial 1 (HS1, 18,000-14,700 cal a. BP), cannot be identified through XRF-Ca analyses. This is because of very low carbonate content in the Black Sea during the last glacial period (Bahr et al., 2005; 2006; Strechie-Sliwinski, 2007). Nevertheless, the identification of the 'Red Layers' (Lithofacies 5) allowed an improvement of the stratigraphy of cores BLKS98-22, BLKS98-23, BLKS98-24 and B2KS-31 since their deposits occurred during HS1, precisely from 17,200 to $15,700 \pm 300$ cal a. BP (Soulet et al., 2011a). The Ti/Ca ratio used for the recognition of the 'Red Layers' on the slope (Bahr et al., 2005, 2006, 2008; Soulet et al., 2011a; see Figure 4) is significantly disturbed in the sequences reported here by the presence of numerous heavy mineral-rich turbidite beds. This explains why both the visual description and the a* parameter were mainly used for the recognition of the 'Red Layers' in the deep Black Sea (Figure 12 and Table 2). Considering their turbiditic origin, it is difficult to determine whether the upper and lower boundaries of 
the 'Red Layers' interval in cores BLKS98-22, BLKS98-23, BLKS98-24 and B2KS-31 strictly correspond to those recognised on the continental slope (e.g. cores GeoB 7806-1 and MD042790; Figure 2). Indeed, the 'red turbidites' could represent only a fraction of the 17,200 to $15,700 \pm 300 \mathrm{cal}$ a. BP interval described from the slope (Soulet et al., 2011a), or even could have been deposited after $15,700 \pm 300$ cal a. BP. This latter assumption can be rejected considering the recognition of a C2 interval (deposited from 14,700 cal a. BP) devoid of 'red turbidites' in cores BLKS98-22, BLKS98-23, BLKS98-24 and B2KS-31. The significant thickness of the sedimentary pile between the last 'red turbidites' and the lower part of the $\mathrm{C} 2$ deposit in the sequences studied here (e.g. $>4 \mathrm{~m}$ in core BLKS98-25) also suggests that a period of significant duration (i.e. the GT2 interval) occurred between these two sedimentary units. Taken together, this sedimentary evidence indicates that deposition of the 'red turbidites' was probably coeval with that of the 'Red Layers' on the continental slope; hence, the authors' decision to synchronize the timing of the 'red turbidites' to that of the 'Red Layers' of Soulet et al. (2011a). The possibility that the 'red turbidites' could represent only a fraction of the 17,200 to $15,700 \pm 300 \mathrm{cal}$ a. BP interval cannot be rejected. However, it ultimately does not preclude significant conclusions being drawn, since in such a case, both sediment accumulation and turbidite frequency presented thereafter have to be considered as minimum estimates.

Radiocarbon age constraints were obtained on core BLKS98-22 (Strechie-Sliwinski, 2007; Assemblage Project, 2007; see Table 3). These ages cannot be easily calibrated since they have been determined from organic matter (cf. Jones and Gagnon, 1994 and Soulet et al., 2011a for a thorough discussion). Jones and Gagnon (1994) demonstrate that a maximum correction (i.e. reservoir age) for radiocarbon ages for Unit I and Unit II sediments is $580 \mathrm{yr}$ for the organic carbon, which is in good agreement with the stratigraphy for this core (Table 3). Conversely, in Unit III, it overestimates the age of the 'Red Layers' by ca. 4,400 yr at least 
(see the sample at $90 \mathrm{~cm}$ in BLKS98-22; Table 3). Radiocarbon dates from below the 'Red Layers' give ages of $24,000 \pm 220{ }^{14} \mathrm{C}$ a. BP, $24,280 \pm 250{ }^{14} \mathrm{C}$ a. $\mathrm{BP}$ and $25,680 \pm 270{ }^{14} \mathrm{C}$ a. BP (Strechie-Sliwinski, 2007; Assemblage Project, 2007; Table 3). Although these radiocarbon dates cannot be calibrated, they approximately indicate that the turbidites described below the 'Red Layers' in core BLKS98-22 below the were deposited immediately before or during the first part of the LGM.

\subsection{Sedimentation rate and turbidite frequency}

The sedimentation rate $(\mathrm{cm} / \mathrm{kyr})$ and the frequency of the turbidite deposition (turb/kyr; e.g. Toucanne et al., 2008, 2012; Jorry et al., 2011; Bonneau et al., 2014) were calculated from sequences BLKS98-22, BLKS98-23, B2KS-31, BLKS98-24, BLKS98-25 and BLKS98-27 for the last 30,000 yr (Figure 14). Six periods of sedimentation and turbidite activity can be described based on the chronostratigraphic framework detailed in Figures 12 and 13, and in Table 2:

1. Before 17,200 cal a. BP (i.e. LGM and HS1), sedimentation rates and turbidite frequencies can be only quantified in core BLKS98-22. Their values are very high, reaching up to ca. $1000 \mathrm{~cm} / \mathrm{kyr}$ and ca. 320 turb/kyr respectively until ca. 28,000 cal a. BP (i.e. $24,000 \pm 220{ }^{14} \mathrm{C}$ a. BP; see Table 3), and rapidly decrease thereafter by a factor 100 between ca. 28,000 and $17,200 \mathrm{cal} \mathrm{a.} \mathrm{BP.}$

2. Between 17,200 to $15,700 \pm 300$ cal a. BP, i.e. during the deposition of the 'Red Layers' (Soulet et al., 2013), the turbidite frequency is relatively low at sites BLKS9822 and BLKS98-23 with 10 and 23 turb/kyr, respectively. The turbidite frequency is higher in core BLKS98-24 with 48 turb/kyr, and reaches a maximum of 154 turb/kyr 
in core B2KS-31. Sedimentation rate is about $170 \mathrm{~cm} / \mathrm{kyr}$ at this site, while it ranges from 35 to $88 \mathrm{~cm} / \mathrm{kyr}$ at sites BLKS98-22, BLKS98-23 and BLKS98-24.

3. From $15,700 \pm 300$ to 14,700 cal a. BP (i.e. Glacial-Type 2, GT2), a remarkable difference is observed between cores. The turbidite frequency is very low with values ranging from no turbidites in core BLKS98-23 to 7 turb/kyr in core B2KS-31. In the same period, very high values are recorded at other sites, from 86 turb/kyr at site BLKS98-24 to $>378$ turb/kyr at site BLKS98-25, with a maximum of $>510$ turb/kyr recorded at site BLKS98-27. The large number of (millimetre-scale) turbidites in core BLKS98-27 during this interval is highlighted in Figures 5 and 11. Sedimentation rates show similar variations with lower values in cores B2KS-31 (46 cm/kyr) and BLKS98-23 (77 cm/kyr) than in cores BLKS98-27 (> $245 \mathrm{~cm} / \mathrm{kyr})$, BLKS98-24 (205 $\mathrm{cm} / \mathrm{kyr})$ and BLKS98-25 (> $430 \mathrm{~cm} / \mathrm{kyr})$.

4. Between 14,700 and 12,650 cal a. BP (i.e. carbonate peak C2, Bølling-Allerød), the highest turbidite frequency is observed in core BLKS98-27 with 131 turb/kyr. In contrast, only 13 turb/kyr are observed in core BLKS98-25, 2 turb/kyr in core BLKS98-24 and none in cores BLKS98-22 and BLKS98-23. The highest sedimentation rates are recorded at site BLKS98-25 (26 cm/kyr) and BLKS98-27 (85 $\mathrm{cm} / \mathrm{kyr})$ while low to very low sedimentation rates $(<10 \mathrm{~cm} / \mathrm{kyr})$ are recorded at the other sites studied.

5. From 12,650 to 11,700 cal a. BP (i.e. Glacial-Type GT1, Younger Dryas), the highest turbidite frequency is recorded in core BLKS98-27 with 176 turb/kyr (sedimentation rates of ca. $120 \mathrm{~cm} / \mathrm{kyr}$ ). For the other sites, the turbidite frequency reaches a maximum in core BLKS98-25, with 21 turb/kyr (sedimentation rates of ca. 55 $\mathrm{cm} / \mathrm{kyr}$ ), while it reaches only 1 to 3 turb/kyr in cores BLKS98-24 and B2KS-31 and turbidites are absent in core BLKS98-22. 
6. Between 11,700 and 8,995 \pm 145 cal a. BP (i.e. carbonate peak C1, Early Holocene), the turbidite frequency at the studied sites is less than 1 turb/kyr, and no activity is recorded at site BLKS98-27. No turbidites are recognised thereafter.

\section{DISCUSSION}

5.1. Sedimentary evolution in the Danube Deep-Sea Fan since the Last Glacial Maximum

The sedimentological data from the Danube Canyon (core BLKS98-27) and the deep-sea fan (cores BLKS98-22, BLKS98-23, BLKS98-24, BLKS98-25 and B2KS-31), coupled with the revised chronostratigraphic framework for the Black Sea recently proposed by Soulet et al. (2011a; 2013), provide the first millennial time-scale record of the sedimentation in the Danube Deep-Sea Fan since the LGM.

Considering that sediment layers on the levees of the Danube Deep-Sea Fan are interpreted as turbidites deposited after the overflow of turbidity current from the adjacent channel, the reconstruction of the turbidite frequency in the BLKS98-22, BLKS98-23, BLKS98-24 and BLKS98-25 and B2KS-31 sequences reveals a continuous activity of the Danube Deep-Sea Fan during the LGM (core BLKS98-22) and throughout Termination 1 (cores BLKS98-22, BLKS98-23, BLKS98-24, BLKS98-25, B2KS-31). The data presented here also suggest a rapid shutdown of the turbiditic activity occurring at the onset of the Holocene period, 11,700 cal a. BP (GT1-C1 transition in the Black Sea; Soulet et al., 2011a) (Figures 14 and 15). This pattern is corroborated for the last ca. $15 \mathrm{kyr}$ by the reconstruction of the turbidite frequency upstream, in the Danube Canyon (core BLKS98-27; see Figure 14), which represents the only entry pathway for turbidity currents towards the channel-levees (Popescu et al., 2004). However, the detailed reconstruction of the turbidite frequency in the levees reveals a 
complex sedimentary evolution over the studied period, with shifts of depocentres locations through time (Figure 14).

Turbidite sedimentation on levees during the LGM is only recorded in the distal part of the fan (cores BLKS98-22 and B2KS-31), along the Southern Channel (Figures 12, 13 and 14). Although no conclusions can be drawn regarding the occurrence of turbidite sedimentation in other levees systems at that time, the chronostratigraphy of the sediment cores provides a new insight into the chronology of the shift of depocentres controlled by the northward migration of the channel-levees avulsions indicated in Figure 3. Core BLKS98-22, located in one of the oldest channel-levee system (Unit U3 of Lericolais et al., 2013; Figure 2) of the last channellevee complex, reveals a rapid decrease in the turbidite activity of the Southern Channel after ca. 28,000 cal a. $\mathrm{BP}$ (i.e. ca. $24,000{ }^{14} \mathrm{C}$ a. BP; Table 3), that can be attributed to the avulsion of the channel leading to the formation of the Middle Channel and the abandonment of the Southern Channel (Figures 2 and 3). This confirms the Late Neoeuxinian age of the upper part of the last channel-levee complex (Lericolais et al., 2013). However, although the Middle and Northern Channel became the preferential turbidite depocentres after the last glacial (see below), the deposition of turbidites persisted in the Southern channel-levee until the end of HS1 (Figures 12, 13 and 14). This indicates that the Southern Channel was not definitely abandoned after the upstream northward avulsion, indicating the possibility that turbidity currents could flow in several channels over the studied period.

The 'Red Layers', identified as a significant stratigraphic marker in the Black Sea, were laid down immediately following the LGM, precisely between 17,200 and $15,700 \pm 300$ cal a. BP (Soulet et al., 2011a). As previously explained, they are interpreted as the record of seasonal meltwater pulses of the Dnieper River in response to ice-marginal fluctuations of the 
Fennoscandian ice-sheet (Soulet et al., 2013). The 'Red Layers' are recognized both in the Southern Channel (cores BLKS98-22, BLKS98-23 and B2KS-31) and in the Middle Channel (core BLKS98-24) (Figures 12 and 13). Interestingly, the 'Red Layers' in the Danube DeepSea Fan are of turbidite origin only, contrary to those described on the outer continental shelf and the upper slope of the western Black Sea that were deposited by hemipelagic processes (Ryan et al., 2003; Bahr et al., 2005, 2006; Soulet et al., 2011a). First, this indicates that the meltwater plumes of the Dnieper River did not reach the deep basin but circulated mainly on the outer continental shelf and the upper slope (e.g. site MD04-2790, Figure 2). This assumption is supported by the presence of olive-grey to beige, homogeneous, structureless silty-clay, interpreted as hemipelagites deposited from the Danube River, between the 'red turbidites' (Figures 5, 8 and 9 for cores B2KS-31 and BLKS98-23). Secondly, it implies that the 'Red Layers', first deposited on the outer shelf and the upper slope, were remobilised and then transported down into the Danube Canyon and deep-sea fan by turbidity currents. If correct, the 'red turbidites' recognised at sites BLKS98-22, BLKS98-23, B2KS-31 and BLKS98-24 indicate that both the Southern and Middle channels were simultaneously active between 17,200 and $15,700 \pm 300 \mathrm{cal}$ a. BP. Another possibility to explain the concomitant deposition of the 'Red Layers' onto the outer shelf and the upper slope (thick mm-scale red laminated deposits; Bahr et al., 2005; Soulet et al., 2011a) and in the Danube Deep-Sea Fan ('red turbidites'), is to consider the occurrence of unconfined hyperpycnal processes, i.e. plunging of hyperpycnal plumes directly from the Dniepr River. A similar downslope sedimentary succession dating for the last deglaciation and originating from the direct entrance of sediment-laden meltwater flows is described on the NW European margin, off the Channel River (Zaragosi et al., 2001; Toucanne et al., 2012). Although this assumption is not fully supported by grain-size measurements (i.e. absence of basal coarsening-upward unit, Figure 8; base cut-out hyperpycnite?), such a process is tenable in the Black Sea at that time 
since hyperpycnal flows are common in lacustrine environments, especially when the streams result from cold meltwater delivery (e.g. Mulder et al., 2003).

The GT2 interval $(15,700 \pm 300-14,700$ cal a. BP $)$ is recorded in all the studied cores and corresponds to the end of HS1 (Figures 12 and 13). The turbidite activity sharply decreases in the Southern Levee (BLKS98-22, BLKS98-23 and B2KS-31), increases in the Middle Levee (BLKS98-24) and is high in the Northern Levee (BLKS98-25) at the end of HS1, precisely from $15,700 \pm 300$ cal a. BP (Figure 14). It is assumed that this sharp transition in the sedimentation marks a significant northwards shift of the depocentre. The highest turbidite frequency (378 turb/kyr) is recorded in the Northern Levee (Figure 8), implying that the Northern Channel was the preferential pathway of turbidity currents and therefore of Danube sediments after $15,700 \pm 300 \mathrm{cal}$ a. BP. The very high turbidite frequencies $(>500 \mathrm{turb} / \mathrm{kyr}$ ) in the Danube Canyon (BLKS98-27) at that time represent a quasi-annual record for the Danube River discharge. This corroborates the evidence for substantial sediment input to the Danube Deep-Sea Fan during the GT2 interval.

At 14,700 cal a. BP, an abrupt decrease in turbidite frequency is observed in the Middle and Northern Channels, and interpreted as a partial shutdown of the Danube Deep-Sea Fan. This change in the deep sedimentation observed at the transition between HS1 and the BøllingAllerød complex is supported by a concomitant decrease in both sedimentation rates and turbidite frequency near the Danube Canyon (core BLKS98-27, Figure 14), that probably suggests a significant decrease of sediment input from the Danube River into the canyon head. A moderate increase of sediment input occurred during the Younger Dryas interval both along the Danube Canyon and in the deep basin (Figure 8), thus revealing a slight reactivation of the Danube Deep-Sea Fan and of the Northern Channel in particular. The latter persists 
until 11,700 cal a. BP. At that time, the turbidite activity in the Danube Canyon and in the deep depositional system stopped. The Danube Deep-Sea Fan remains sediment-starved throughout the Holocene (Figure 14).

5.2. Factors controlling the Danube Deep-Sea Fan sedimentation: sediment flux versus waterlevel fluctuations

The overall activity of the Danube Deep-Sea Fan reflects, to a certain extent, the effectiveness of the connection between the Danube River and the Danube Canyon, the latter representing the main pathway for the transport of the sediments to the deep depositional system (Popescu et al., 2001). An efficient connection between the river mouth and the canyon represents a prerequisite for enhanced sediment flux to the deep basin. The deep incision of the Danube Canyon into the shelf, $26 \mathrm{~km}$ landward from the shelf-break, up to $-110 \mathrm{~m}$ water depth (Popescu et al., 2004; Figure 2), clearly favoured the connection of the Danube delta (its distal part at least) with the deep basin at lowstand conditions in the Black Sea $(\leq-110 \mathrm{~m})$ or even maybe at higher stand conditions (i.e. sea-level $>-110 \mathrm{~m}$ ) if the river sediment flux was important enough to lead to a sufficient seaward progradation of the delta. This point is discussed for each of the main climatic periods identified in this study.

\subsubsection{The last glacial period (LGM and Heinrich Stadial 1)}

During the LGM period, the significant amount of turbidites recognised in the system (site BLKS98-22 until ca. 28,000 cal a. BP, and levee growth of the Middle channel-levee system thereafter) suggests an efficient river-canyon connection, an expected result with regard to the palaeoenvironmental conditions. Indeed, the level of the Black Sea 'Lake' was probably about 
150-100 m lower than present sea-level at that time (Ryan et al., 1997; Winguth et al., 2000; Aksu et al., 2002; Lericolais et al., 2009, 2011). At this time the sediment load of the western Black Sea rivers, including the Danube River, was higher than today (Figure 15; Sidorchuk et al., 2008, 2011; Kasse et al., 2010). The Tisza River, a tributary of the Danube River, shows that the maximum surface runoff peak discharges and sediment supply occurred during the LGM then decreased in the second part of Termination 1 (Kasse et al., 2010). In addition, it is well-known that $80 \%$ of the Late Würmian ice volume in the Alps had melted by 18,000 cal a. BP (Ivy-Ochs et al., 2008), and one can assume that the melting of the Alpine ice-sheet (and of glaciers in the Tatra Mountains; Makos et al., 2013) and the high sediment yield of the Alps (i.e. large masses of unconsolidated materials available, scarce vegetation and high transport capacities; Hinderer, 2001) strongly enhanced the Danube River discharge into the Black Sea 'Lake' after the LGM. Such a result is consistent with sediment flux reconstructions for rivers connected to the Alps at the end of the last glacial, including the rivers Po and the Rhône (Kettner and Syvitski, 2008, 2009). The sediment flux of the Danube River was then funnelled directly into the Danube Canyon and rapidly transferred to the deep basin. The data presented here shows an important turbidite activity in the Southern Channel, yet the lack of stratigraphic constraints makes it difficult to estimate for the whole system.

The abrupt drainage of the Fennoscandian ice-sheet between ca 17,200 and 15,700 $\pm 300 \mathrm{cal}$ a. BP caused a ca. $100 \mathrm{~m}$ rise in the water-level of the Black Sea 'Lake' according to Soulet et al. (2013) (Figure 15). Although not well quantified, such a rise has been identified in many studies (e.g. Major et al., 2006; Bahr et al., 2008; Kwiecien et al., 2009). At the same time, the coastline (and the Danube River mouth) retreated ca. $100 \mathrm{~km}$ northwest of the Black Sea shelf, implying a complete submersion of the modern head of the Danube Canyon and a possible outflow into the Marmara Sea (i.e. water-level at ca. $-30 \mathrm{~m}$, that correspond to the 
detph of the Bosphorus sill; Soulet et al., 2011a; Aloisi et al., 2015). Surprisingly, the turbidite flows continued to feed the Southern and Middle Channels as revealed by the recognition of the 'red turbidites' that originated from the Dnieper River at sites BLKS98-22, BLKS98-23, B2KS-31 and BLKS98-24. This indicates that the Dnieper River was the main source for the Danube Deep-Sea Fan at that time, and that the Danube delta was probably not important enough to reach the Danube Canyon head. This result is corroborated by the estimated time of ca. $11 \mathrm{kyr}$ for the modern Danube River to form a shelf-edge delta (Burgess and Hovius, 1998), thus excluding the possibility that the Danube could reach the canyon head to feed the deep-depositional system during this period of water-level rise. The process of sediment transport from the Dnieper River to the Danube Deep-Sea Fan remains unclear, involving either hyperpycnal flows or deposition-remobilisation onto the shelf and the upper slope before capture by the Danube Canyon and then downslope transport through surge-like turbidity current. Importantly, both processes can occur during water-level highstand, thus reconciling the activity of the Danube Deep-Sea Fan at time of relative high sea-level conditions.

The GT2 period $(15,700 \pm 300-14,700 \mathrm{cal}$ a. BP $)$, that corresponds to the end of Heinrich Stadial 1 , is characterised by the highest sediment input observed into the Danube Deep-Sea Fan through the studied period (Figure 14). The high turbidite activity at sites BLKS98-24 (Middle Channel), BLKS98-25 (Northern Channel) and BLKS98-27 (Danube Canyon) suggests that the Danube River was connected again to the Danube Canyon at that time. Considering the highstand conditions (ca. $-30 \mathrm{~m}$ ) of the Black Sea 'Lake' at 15,700 $\pm 300 \mathrm{cal}$ a. BP (see discussion above; Figure 15), such a connection involves either a significant seaward progradation of the delta (under stillstand conditions; e.g. Aloisi et al., 2015) or renewed lowstand conditions at the end of Heinrich Stadial 1. The first assumption cannot be 
totally rejected since the persistence of cold, arid conditions in Central Europe until 14,700 cal a. BP (e.g. Niessen et al., 1992; Antoine et al., 2009; Kwiecien et al., 2009), associated with scarce vegetation (high abundance in xerophytic steppe, grassland and dry shrubland in the pollinic sequence of Central Europe and Romania; Feurdean et al., 2014) favoured soil erosion in the river basins as well as sediment transfer (Kasse et al., 2010). The latter is a prerequisite for the progradation of the Danulbe delta under stillstand conditions. Nevertheless, the estimated time for the modern Danube River to form a shelf-edge delta (Burgess and Hovius, 1998) strongly challenge a rapid, significant progradation of the Danube delta as a forcing for enhanced sediment input into the Danube Deep-Sea Fan during the GT2 period. In contrast, the cessation of the meltwater input from the Fennoscandian icesheet at 15,700 $\pm 300 \mathrm{cal}$ a. BP (Soulet et al., 2011a; Soulet et al., 2013) and the persistence of arid conditions until $14,700 \mathrm{cal}$ a. BP could have led to a negative hydrological balance of the Black Sea 'Lake' which, in turn, could have caused a sharp water-level drawdown and an intense feeding of the deep-depositional system (i.e. water-level $\leq-110 \mathrm{~m}$, that correspond to the depth of the head of Danube Canyon; Figure 15). Numerical modelling demonstrate that the Black Sea 'Lake' level could have significantly lowered in a few centuries in response to past hydrological changes (i.e. negative hydrological budget) in the Black Sea watershed (Georgievski and Stanev, 2006). Such a millennial-scale lowstand event has yet to be identified from seismic data, or in sediment sequences. It also contradicts previous results that suggest that the ouflow of the Black Sea 'Lake' into the Marmara Sea that began in response to the abrupt drainage of the Fennoscandian ice-sheet persisted until the end of Heinrich Stadial 1 (Soulet et al., 2011a; Aloisi et al., 2015). Nevertheless, it is interesting to note that a shift in the depocentre location from the Southern to the Middle Channel occurred when the Black Sea Meltwater Pulses stopped, ca. 15,700 \pm 300 yr ago. Previous works focusing on deep depositional systems have shown the direct impact of sea-level changes on changes in 
sediment depocentres (e.g. Maslin et al., 2006). Although the forcing remains unclear and the authors' assumption requires testing, the profound re-equilibrium of the turbidite system at $15,700 \pm 300 \mathrm{cal}$ a. BP reveals strong paleoenvironmental changes in the studied area at the end of Heinrich Stadial 1.

\subsubsection{The Late Glacial (Bølling-Allerød, Younger Dryas) and the Holocene}

Increased humidity and vegetation spreading occurred in Central Europe from 14,700 to ca 13,000 cal a. BP, i.e. during the Bølling-Allerød warm interval (Niessen et al., 1992; Kasse et al., 2010; Feurdean et al., 2014; Magyari et al., 2014). This period is marked by a warming of 5-10 ${ }^{\circ} \mathrm{C}$ in the Black Sea region (Soulet et al., 2011a; Ménot and Bard, 2012), associated with an important rise in the mean annual volume runoff of the East European rivers at the beginning of the period (Sidorchuk et al., 2011) (Figure 15). A drastic diminution of the runoff followed, probably in response to the vegetation migrating and the subsequent increased in soil stability (Sidorchuk et al., 2011). These palaeoenvironmental changes, emphasised by the substantial change in fluvial style (from braided to meandering) in the Danube watershed (Kasse et al., 2010; Figure 15) might probably explain the concomitant decrease in turbidite activity observed both in the deep basin and in the Danube Canyon (Figure 15). One interesting point is the decline of turbidite frequency on the levees while sediment flux remains high near the canyon (Figure 14). This indicates that the river-canyon connexion during the Bølling-Allerød was not as efficient as during the LGM and the second part of Heinrich Stadial 1. As a result, we assume that the Danube delta was close to the canyon head, but not sufficiently close to deliver the sediment directly into the canyon. If correct, this indicates that the water level of the Black Sea 'Lake' was low during the BøllingAllerød interval, but necessarily above $-110 \mathrm{~m}$. By considering modern rates of delta 
progradation (Burgess and Hovius, 1998), it is assumed that a water-level of -70 m (i.e. delta progradation of ca. 50-60 km to reach the canyon head) as an upper limit for the Black Sea 'Lake' (Figure 15). This indicates persistent lowstand conditions in the Black Sea 'Lake' throughout the Bølling-Allerød, as previously shown by Major et al. (2006) and Hiscott et al. (2007) (Figure 15). This assumption is supported by Bahr et al. (2006) who discuss the impact of enhanced freshwater influence by the Danube during a period of lowered Black Sea lake level between 14,500 and $12,500 \mathrm{cal}$ a. BP. A relatively high turbidite activity persisted in the Danube Canyon during the Younger Dryas (12,800-11,700 cal a. BP), indicating to the relative proximity of the Danube delta. One can assume that the river-canyon connexion, possibly similar to that described for the Bølling-Allerød, was related to persistent lowstand conditions (e.g. Georgievski and Stanev, 2006; Lericolais et al. 2007, 2009, 2010, 2011; Nicholas et al., 2011) since the second part of Heinrich Stadial 1 (see discussion above). However, Major et al. (2006) suggest that the Black Sea level may have been rising through the Younger Dryas interval, perhaps as high as its outflow at around - $30 \mathrm{~m}$. A rise in waterlevel cannot be rejected but the latter would has been moderate given the persistence of high sediment flux in the Danube Canyon and even the slight increase of the turbidite activity in the Danube Deep-Sea Fan (Danube Canyon and Northern Channel especially, see Figure 14) at that time.

The turbidite activity in the Danube Deep-Sea Fan ultimately stopped at 11,700 cal a. BP, i.e. at the Younger Dryas - Holocene transition, suggesting a close relationship between the feeding of the deep basin and climate changes. Since the sediment yield of the European rivers increased from the Younger Dryas to the Holocene in response to an increase in precipitation (Kettner and Syvitski, 2008), the cessation of the fan activity implies a rivercanyon disconnection that probably originates from a rise of the water-level well above $-70 \mathrm{~m}$ 
(see discussion above). Such a rise after the Younger Dryas probably resulted from the enhanced rainfalls described in the Black Sea and Eastern Mediterranean regions at that time (Fleitmann et al., 2009; Badertscher et al., 2011; Göktürk et al., 2011). This result does not match the water-level reconstructions of Lericolais et al. (2007, 2009, 2010; i.e. major lowstand base-level at around $-100 \mathrm{~m}$ before the Early Holocene connection, Figure 15) and Nicholas et al. (2011; i.e. water-level at $-107 \mathrm{~m})$ but is supported by the results of Aksu et al. (2002), Hiscott et al. (2007b; Outflow Hypothesis II; Figure 15), Giosan et al. (2009), Mudie et al. (2014) and Yanko-Hombach et al. (2014) who stated that the Black Sea level stood at about $-40 \mathrm{~m}$ during the Early Holocene. Relative highstand conditions are also supported by the initial formation of the Letea-Caraornam spit, a main geomorphological feature of the modern Danube delta, from 11,700 cal a. BP (Panin et al., 1983). The recognition of the ca. 20-30 cm thick turbidite-free sapropel layer in all the studied cores (e.g. core B2KS-31; Figure 7 and Table 2) shows that the Danube Deep-Sea Fan did not react to the subsequent reconnection of the Black Sea 'Lake' with the global ocean at ca. 9,000 cal a. BP.

The results presented demonstrate that external forcing controlled the sedimentation in the Danube Deep-Sea Fan since the LGM. The latter, when compared with existing reconstructions for climate changes and river activity in the region, gives new insights into past water-level reconstructions of the Black Sea 'Lake'. In summary, it is assumed that lowstand conditions ( $\leq-110 \mathrm{~m}$; i.e. depth of the head of the Danube Canyon) prevailed during the LGM and possibly between $15,700 \pm 300-14,700 \mathrm{cal}$ a. $\mathrm{BP}$, and that water-level ranged from $\geq-110 \mathrm{~m}$ and $\leq-30 \mathrm{~m}$ (i.e. depth of the Bosphorus sill) between ca. 17,200 and 15,700 \pm $300 \mathrm{cal}$ a. BP and between 14,700 cal a. BP and the reconnection of the Black Sea to the global ocean ca 9,000 cal a. BP. By considering an upper limit for river-canyon connexion at ca. $-70 \mathrm{~m}$ (see discussion above), it is proposed for this last period a water-level ranging from 
$\geq-110$ and $\leq-70 \mathrm{~m}$ between 14,700 and $11,700 \mathrm{cal} \mathrm{a}$. BP, and from $\geq-70$ and $\leq-30 \mathrm{~m}$ between 11,700 and 9,000 cal a. BP (Figure 15).

\section{CONCLUSIONS}

The detailed sedimentological and geochemical analysis of sediment collected in six piston cores from the western Black Sea, through the determination of sedimentary facies, acquisition of high-resolution records of chemical composition and reconstruction of sediment accumulation rates and turbidite frequency, provides the first continuous depositional history of the Danube Deep-Sea Fan since the Last Glacial Maximum (LGM). The following conclusions can be drawn:

(i) the Danube Deep-Sea Fan was active during the LGM and until the Younger Dryas - Early Holocene transition ca. 11,700 cal a. BP, when the turbidite activity abruptly stopped in the whole system. Since the Black Sea was a giant lake before ca. 9000 cal a. BP, the Danube Deep-Sea Fan was then a deep lacustrine depositional system;

(ii) the Danube River was the main source of the deep depositional system during the studied period, except during the deposition of the Red 'turbidites' Layers ('red turbidites') in the deep basin, ca. 17,200 - 15,700 $\pm 300 \mathrm{cal}$ a. BP. Although the precise process of sediment transport remains unclear, the latter result from the increased runoff of the Dnieper River in response to abrupt drainage of the Fennoscandian ice sheet;

(iii) Some significant changes in the location of the depocentre of the Danube Deep-Sea Fan occurred through time. The main change in depocentre location occurred at ca. 28,000 cal a. $\mathrm{BP}$, with the northward avulsion leading to the formation of the Middle Channel. Although 
the Middle and Northern Channel became the preferential turbidite depocentres after this event, the deposit of turbidites have persisted in the Southern channel-levee until 14,700 cal a. BP indicating that the Southern Channel was not definitely abandoned after the upstream northward avulsion;

(iv) Comparison of the results obtained with existing reconstructions for climate changes and river activity in the Black Sea region reveals that both the activity and evolution of the Danube Deep-Sea Fan were controlled by external forcing fluctuations. The turbidite activity is very sensitive to water-level fluctuations since the connection between the Danube River and the Danube Canyon (canyon head at $-110 \mathrm{~m}$ ) constitutes a prerequisite for sediment transfer towards the deep basin. The reconstruction of the turbidite activity provides a revised curve for Black-Sea water-level fluctuations that shows that $(i)$ lowstand conditions $(\leq-110$ m) prevailed during the LGM and possibly between $15,700 \pm 300-14,700$ cal a. BP, (ii) water-level ranged from $\geq-110 \mathrm{~m}$ and $\leq-30 \mathrm{~m}$ between ca. 17,200 and 15,700 $\pm 300 \mathrm{cal}$ a. BP and between 14,700 cal a. BP and the reconnection of the Black Sea to the global ocean ca 9,000 cal a. BP. By considering an upper limit for river-canyon connexion (through delta progradation) at ca. $-70 \mathrm{~m}$, the findings here suggest for the latter period a water-level ranging from $\geq-110$ and $\leq-70 \mathrm{~m}$ between 14,700 and 11,700 cal a. BP, and from $\geq-70$ and $\leq-30 \mathrm{~m}$ between 11,700 and 9,000 cal a. BP (Figure 15). 


\section{ACKNOWLEDGMENTS}

The authors are very grateful to M. Rovere, A. Roubi (IFREMER), J. Saint-Paul and I. Billy (Université de Bordeaux) for their technical support, F. Guichard (LSCE) for core analysis, J. Etoubleau (IFREMER) for assistance on the Avaatech XRF core scanner, V. Cuq (University of Brest) for assistance on the Malvern Mastersizer 2000, J. Giraudeau (Université de Bordeaux) for identification of coccolithophore species, C. Pop (GeoEcoMar, Bucharest) for GIS assistance, V. Riboulot (IFREMER) for the drawing of figure 3 and M. Charidemou (Cardiff University) and P.L. Gibbard (University of Cambridge) for English improvements. The authors also warmly thank G. Soulet and G. Jouet for invaluable discussions at various stages of this work. They finally thank the crew and scientific teams of the BLASON cruises for the recovery of the piston cores. A.M.C. acknowledges the partial funding from the French Government and the active help of B. de Boisdeffre, F. Flori and the French Embassy in Bucharest, Romania. The authors also thank N. Panin. Gh. Oaie and A. Stanica (GeoEcoMar, Bucharest) for their formal support in carrying out this study. The authors finally acknowledge both the reviewers and the Editor for their helpful comments, which greatly improved this paper. This work is a contribution to the IFREMER project PJ2207 'Systèmes et Evolutions Sédimentaires', and to the 'Assessment of the Black Sea Sedimentary System Since the Last Glacial Extreme' (ASSEMBLAGE) project conducted by G.L. and funded by European Commission Grant EVK3-CT-2002-00090. 


\section{TABLE CAPTION}

Table 1. Key parameters of cores discussed in this study including core number, geographical position, water depth, length and physiography.

Table 2: Detailed stratigraphic correlation for the studied cores. Ages according to Jones and Gagnon (1994; MCO / Sapropel transition) and Soulet et al. (2011a). Details regarding the identification of the stratigraphic markers are indicated.

Table 3: ${ }^{14} \mathrm{C}$ (organic matter) for core BLKS98-22 (Strechie-Sliwinski, 2007; Assemblage Project, 2007). They correspond to the yellow stars in Figures 12 and 13. LSCE $=$ Laboratoire des Sciences du Climat et de l'Environnement, Gif-sur-Yvette, France; CAMS = Center for Accelerator Mass Spectrometry, Lawrence Livermore National Laboratory, USA. Radiocarbon ages are calibrated by using a correction of $580 \mathrm{yr}$ for organic matter (Jones and Gagnon, 1994). This correction is unsuitable for samples from Unit III (age marked by an asterisk; see the main text for details). 


\section{FIGURE CAPTION}

Figure 1. The Danube Deep-Sea Fan (NW Black Sea - solid blue area), and the regional palaeogeographical context during the Last Glacial Maximum (LGM) showing the extent of the Fennoscandian Ice Sheet (FIS) and the Alpine Ice Sheet (AIS) (white shaded areas) (Ehlers et al., 2011). Blue lines show the course of the Danube, Dnieper and Tisza rivers discussed in the main text. The $-110 \mathrm{~m}$ bathymetric line on the NW Black Sea shelf corresponds to the bathymetry of the head of the Danube Canyon (Popescu et al., 2004).

Figure 2. Detailed bathymetric map of the Danube Deep-Sea Fan. The red lines depict the channel-levees systems. Yellow dots show the location of the studied cores: core BLKS98-27 along the Danube Canyon, cores BLKS98-22, BLKS98-23 and B2KS-31 in the Southern Channel, core BLKS98-24 in the Middle Channel, and core BLKS98-25 in the Northern Channel. The MD04-2790 core located on the upper slope is the stratigraphic reference used in this study (Soulet et al., 2011a). Cores BLKS98-10 (Major et al., 2002) and GeoB 7806-1 (Bahr et al., 2005, 2006, 2008) are cited in the main text and shown in Figure 4. Seismic units U0 to U6 (i.e. relative chronology for avulsion) refer to Lericolais et al. (2013). These units correspond to the sequence 8 of Winguth et al. (2000), deposited during the last glacial lowstand or (Post Karangatian-) Neoeuxinian period according to these authors. The $-110 \mathrm{~m}$ bathymetric (thick white) line on the NW Black Sea shelf corresponds to the bathymetry of the head of the Danube Canyon (Popescu et al., 2004). The location of the BLASON 24channel seismic line 7 is shown (see Figure 3).

Figure 3. Part of BLASON 24-channel seismic line 7 (see the location in Figure 2) redrawn from Popescu et al. (2001), and emphasising the northward avulsion of the channel-levee 
systems in the Danube Deep-Sea Fan through time. The location (with length) of core BLKS98-25 (Northern Channel), core BLKS98-24 (Middle Channel), and cores B2KS-31, BLKS98-23 and BLKS98-22 (Southern Channel) is shown. The sedimentary sequence above the BN (base of Neoeuxinian) boundary corresponds to the U0-U6 units (i.e. relative chronology for avulsion) of Lericolais et al. (2013) (Figure 2) and to the sequence 8 of Winguth et al. (2000), deposited during the last glacial lowstand (i.e. MIS 4-2 or Neoeuxinian period) according to these authors. HARPS: high-amplitude reflection packets (i.e. early stage of non-channelised deposition after channel avulsion); MTD: mass-transport deposit.

Figure 4. Evolution of the carbonate content $(\% \mathrm{CaCO} 3$ and XRF-Ca) in the western Black Sea (northwestern part for cores BLKS98-10, GeoB 7806-1 and MD04-2790, see their location on Figure 2; southwestern part for core MD04-2788/2760) since the LGM, and comparison of the age models published by Major et al. (2002), Kwiecien et al. (2008), Bahr et al. (2008) and Soulet et al. (2011a) for core BLKS98-10, MD04-2788/2760,GeoB 7806-1 and MD04-2790, respectively. Note the ubiquitous nature of the evolution of the carbonate signal in the Black Sea over the studied period. Units U.I, U.II and U.III refer to the sedimentary units of Degens and Ross (1972) that testify the change from lacustrine (Unit III, banded lutite, deposited before $8080 \pm 250$ cal a. BP according to Soulet et al., 2011b) to marine conditions (Unit II, sapropel, until $2720 \pm 160 \mathrm{cal} \mathrm{a.} \mathrm{BP,} \mathrm{according} \mathrm{to} \mathrm{Jones} \mathrm{and}$ Gagnon, 1994, overlaid by Unit I, microlaminated coccolith ooze). TOM: Transitional olive mud (lithofacies 3, L.3); MCO: microlaminated coccolith ooze (lithofacies 1, L.1); IMI: Initial Marine Inflow; GT1 and GT2: Glacial Transitions; RL: Red Layers; G: Glacial.

Figure 5. Examples of some representative photographs and X-rayed slabs of the main facies (i.e. lithofacies 1 to 6, L.1 to L.6) described in the Danube Canyon (core BLKS98-27) and in 
the Danube Deep-Sea Fan (i.e. sedimentary levees, cores BLKS98-22, BLKS98-23, B2KS31 , and illustrating the evolution of the sedimentation in the deep depositional system since the Last Glacial Maximum. Turbidite facies are detailed in Figures 8, 9, 10 and 11.

Figure 6. Scanning electron microscope image detailing the biogenic (calcareous) composition (coccolithophores, Emiliania huxleyi) of white laminae in the microlaminated coccolith ooze (MCO) facies (core BLKS98-23). This image has been obtained by backscattered electrons with an accelerating voltage of $20 \mathrm{kV}$.

Figure 7. Sedimentological and geochemical evolution on the NW Black Sea margin through Termination 1, and stratigraphic correlation between core B2KS-31 (Danube Deep-Sea Fan, Southern Channel) and core MD04-2790 (upper continental slope, NW Black Sea; Soulet et al., 2011a) based on millimetre-scale XRF core scanner measurements $\left(\mathrm{Ca}_{\text {norm }}\right.$ and $\mathrm{Ti} / \mathrm{Ca}$ ratio). The chronology used here refers to that of Soulet et al. (2011a). See Figure 4 for details about sedimentological, geochemical and stratigraphic boundaries.

Figure 8. Photograph, X-ray image, millimetre-scale XRF core scanning data and grain-size data of the reddish turbidite-rich silty clay (with the 'red turbidites'; lithofacies 5) in core BLKS98-23 (Southern Channel). The sediment here presented is from the 'Red Layers' interval (i.e. from 17,200 to $15,700 \pm 300 \mathrm{cal}$ a. $\mathrm{BP}$ ). Note that values for $\mathrm{Ca} / \mathrm{Fe}$ are multiplied by 5 for easy comparison with $\mathrm{Ca}_{\text {norm }}$ values. Open circles on the $\mathrm{X}$-ray image represent the samples used for grain-size analysis. D50 (D84) = grain-size at which $50 \%(84 \%)$ of the sample is finer. Grey layers and associated arrows represent turbidite deposits and fining upwards trend, respectively. Note that this facies strongly differs from the millimetre-scale, IRD-rich, red laminated deposits (the so-called 'Red Layers') described on the outer 
continental shelf and the upper slope (Major et al., 2002; Bahr et al., 2005; Soulet et al., 2011a).

Figure 9. Photograph, X-ray image, millimetre-scale XRF core scanning data and grain-size data of fine-grained turbidites (lithofacies 6) in core B2KS-31 (Southern Channel). The sediment here presented is from the 'Red Layers' interval (i.e. from 17,200 to $15,700 \pm 300 \mathrm{cal}$ a. BP). Note that values for $\mathrm{Ca} / \mathrm{Fe}$ are multiplied by 5 for easy comparison with $\mathrm{Ca}_{\text {norm }}$ values.

Figure 10. Photograph, X-ray image, millimetre-scale XRF core scanning data and grain-size data of very-fine fine-grained turbidites (lithofacies 6) in core BLKS98-22 (Southern Channel). The sediment here presented is from the glacial interval (i.e. LGM). Note that values for $\mathrm{Ca} / \mathrm{Fe}$ are multiplied by 4 for easy comparison with $\mathrm{Ca}_{\text {norm }}$ values.

Figure 11. Photograph, X-ray image and millimetre-scale XRF core scanning data of very fine-grained turbidites (lithofacies 6) in core BLKS98-27 (Danube Canyon). The sediment here presented is from the GT2 interval (i.e. from $15,700 \pm 300$ to 14,700 cal a. BP). The white box on the X-ray image shows the location of the XRF measurements.

Figure 12. Core-to-core correlations between the Danube Deep-Sea Fan and the reference core MD04-2790 (Soulet et al., 2001a) based on high-resolution XRF core scanner $\left(\mathrm{Ca}_{\text {norm }}\right.$ and $\mathrm{Ti} / \mathrm{Ca}$ ratio) and spectrophotometric measurements [a* values range from -60 (green) to +60 (red)]. Yellow stars indicate the position of ${ }^{14} \mathrm{C}$ ages (Table 3). See Figure 4 for details about sedimentological, geochemical and stratigraphic boundaries. 
Figure 13. Sedimentary evolution in the Danube Deep-Sea Fan since the LGM, and core-tocore correlations with the reference core MD04-2790 (Soulet et al., 2001a). Correlations are based on high-resolution XRF core scanner ( $\mathrm{Ca}$ and $\mathrm{Ti} / \mathrm{Ca}$ ratio) and spectrophotometric measurements [a* values range from -60 (green) to +60 (red)] presented in Figure 12. Yellow stars show the position of ${ }^{14} \mathrm{C}$ ages (Table 3). See Figure 4 for details about sedimentological, geochemical and stratigraphic boundaries. C: clay; SC: silty-clay; S: silt; VF: very fine sand; F: fine sand; M: medium sand; C: coarse sand; VC: very coarse sand.

Figure 14. Evolution of sedimentation rates (green histograms $-\mathrm{cm} / \mathrm{kyr}$ ) and of turbidite deposit frequency (continuous red line - turb/kyr) in cores BLKS98-27 (Danube Canyon), BLKS98-25 (Northern Channel), BLKS98-24 (Middle Channel), BLKS98-22, BLKS98-23 and B2KS-31 (Southern Channel) since the LGM. Note that the calculations for core BLKS98-22 do not include the radiocarbon age of 25,680 $\pm 270{ }^{14} \mathrm{C}$ a. BP (StrechieSliwinski, 2007; Assemblage Project, 2007) since it caused reversal in the age-depth model (Table 3). See Figure 4 for details about sedimentological, geochemical and stratigraphic boundaries.

Figure 15. (A) Synthesis of the turbidite activity in the Danube Canyon (blue line; core BLKS98-27) and in the Danube Deep-Sea Fan (green histogram; mean turbidite frequency for cores BLKS98-25, BLKS98-24, BLKS98-23, BLKS98-22 and B2KS-31) since the LGM. Note that the turbidite activity in the Danube Deep-Sea Fan before HS1 (light green histogram) only based upon core BLKS98-22 (Southern Channel; Figure 2), with the rapid decrease in turbidite frequency at ca. 28,000 cal a. BP highlighting the avulsion leading to the formation of the Middle Channel and the abandon of the Southern Channel. Since core BLKS98-24 (Middle channel) only extends back to ca. 18,000 cal a. BP (i.e. do not record the 
first step of the development of the Middle channel-levee system), the synthesis of the turbidite activity between ca. 28,000 and $18,000 \mathrm{cal}$ a. BP is not relevant at the regional scale. The turbidite activity is correlated with (C) the surface runoff for East European rivers (Sidorchuk et al., 2011) and (D) the fluvial style changes in the middle Tisza valley (Danube tributary, Hungary; Kasse et al., 2010). (B) Reconstruction of the Black Sea 'Lake' level fluctuations. Thick, black line after Soulet et al. (2011a, 2011b); thin, black line and blue diamonds (seismic sequences dated) after Lericolais et al. (2011, 2013); dashed red area, probability inferred from the data of the present study. Note that a water-level of $-70 \mathrm{~m}$ (i.e. delta progradation of ca. 50-60 km to reach the canyon head) is considered as the upper limit for possible river-canyon connexion. 


\section{REFERENCES}

Aksu, A.E., Hiscott, R.N., Yasar, D., Isler, F.I., Marsh, S., 2002. Seismic stratigraphy of Late Quaternary deposits from the southwestern Black Sea shelf: evidence for noncatastrophic variations in sea-level during the last $~ 10000$ yr. Marine Geology 190, 61-94.

Antoine, P. et al., 2009. High-resolution record of the last climatic cycle in the southern Carpathian Basin (Surduk, Vojvodina, Serbia). Quaternary International 198, 19-36.

Assemblage Project, 2007. ASSEssMent of the BLAck Sea sedimentary system since the last Glacial Extreme, European Commission Grant EVK3-CT-2002-00090, Delivrable 14 'Isotopes and Age dating'. Available on http://www.ifremer.fr/assemblage/index.htm.

Badertscher, S., Fleitmann, D., Cheng, H., Edwards, R.L., Güktürk, O.M., Zumbühl, A., Leuenberger, M., Tüysüz, O., 2011. Pleistocene water intrusions from the Mediterranean and Caspian seas into the Black Sea. Nature Geoscience 4, 236-239.

Bahr, A., Arz, H.W., Lamy, F., Wefer, G., 2006. Late glacial to Holocene paleoenvironmental evolution of the Black Sea, reconstructed with stable oxygen isotope records obtained on ostracod shells. Earth and Planetary Science Letters 241, 863-875.

Bahr, A., Jiménez-Espejo, F.J., Kolasinac, N., Grunert, P., Hernández-Molina, F. J., Röhl, U., Voelker, A.H.L., Escutia, C., Stow, D.A.V., Hodell, D., Alvarez-Zarikian, C.A., 2014. Deciphering bottom current velocity and paleoclimate signals from contourite deposits in the Gulf of Cádiz during the last $140 \mathrm{kyr}$ : An inorganic geochemical approach. Geochemistry, Geophysics, Geosystems 15(8), 3145-3160.

Bahr, A., Lamy, F., Arz, H.W., Kuhlmann, H., Wefer, G., 2005. Late glacial to Holocene climate and sedimentation history in the NW Black Sea. Marine Geology 214, 309322.

Bonneau, L., Jorry, S.J., Toucanne, S., Silva Jacinto, R., Emmanuel, L., 2014. Millennialscale response of a western Mediterranean river to climate changes: A view from the deep sea. Journal of Geology 122(6), 687-703.

Burgess, P.M., Hovius, N., 1998. Rates of delta progradation during highstands: consequences for timing of deposition in deep-marine systems. Journal of the Geological Society 155(2), 217-222.

Chepalyga, A.L., 1985. Inland sea basins. In: Velichko, A.A. (Ed.), Late Quaternary Environments of the Soviet Union. University of Minnesota Press, Minneapolis, pp. $229-247$.

Clark, P.U., Dyke, A.S., Shakun, J.D., Carlson, A.E., Clark, J., Wohlfarth, B., Mitrovica, J.X., Hostetler, S.W., McCabe, A.M., 2009. The Last Glacial Maximum. Science 325, 710 714. 
Croudace, I.W., Anders, R., Rothwell, R.G., 2006. ITRAX: description and evaluation of a new multi-function X-ray core scanner. In: R.G. Rothwell (Editor), New Techniques in Sediment Core Analysis. Geological Society, London, Special Publications 267, 51 63.

Dean, W.E., Arthur, M.A., 2011. Geochemical characteristics of Holocene laminated sapropel (unit II) and underlying lacustrine unit III in the Black Sea U.S. Geological Survey Open-File Report 2010-1323, 29 p.

Debret, M., Sebag, D., Desmet, M., Balsam, W., Copard, Y., Mourier, B., Susperrigui, A.S., Arnaud, F., Bentaleb, I., Chapron, E., Lallier-Vergès, E., Winiarski, T., 2011. Spectrocolorimetric interpretation of sedimentary dynamics: The new "Q7/4 diagram". Earth-Science Reviews 109, 1-19.

Degens, E.T., Ross, D.A., 1972. Chronology of the Black Sea over the last 25,000 years. Chemical Geology 10, 1-16.

Deuser, W.G., 1972. Late Pleistocene and Holocene history of the Black Sea as indicated by stable isotope studies. Journal of Geophysical Research, 77, 1071-1077.

Ehlers, J., Gibbard, P.L. and Hughes, P.D., 2011. Quaternary Glaciations - Extent and Chronology, 15. Elsevier, Amsterdam, 1126 pp.

Feurdean, A., Persoiu, A., Tantau, I., Stevens, T., Magyari, E.K., Onac, B.P., Markovic, S., Andric, M., Connor, S., Farcas, S., Galka, M., Gaudeny, T., Hoek, W., Kolaczek, P., Kunes, P., Lamentowicz, M., Marinova, E., Michczynska, D.J., Persoiu, I., Plociennik, M., Slowinski, M., Stancikaite, M., Sumegi, P., Svensson, A., Tamas, T., Timar, A., Tonkov, S., Toth, M., Veski, S., Willis, K.J., Zernitskaya, V., 2014. Climate variability and associated vegetation response throughout Central and Eastern Europe (CEE) between 60 and 8 ka. Quaternary Science Reviews 106, 206-224.

Fleitmann, D., Cheng, H., Badertscher, S., Edwards, R.L., Mudelsee, M., Göktürk, O.M., Fankhauser, A., Pickering, R., Raible, C.C., Matter, A., Kramers, J. and Tüysüz, O., 2009. Timing and climatic impact of Greenland interstadials recorded in stalagmites from northern Turkey. Geophysical Research Letters 36, L19707.

Giosan, L., Filip, F., Constantinescu, S., 2009. Was the Black Sea catastrophically flooded in the early Holocene? Quaternary Science Reviews 28, 1-6.

Göktürk, O. M., Fleitmann, D., Badertscher, S., Cheng, H., Edwards, R. L., Leuenberger, M., Frankhauser, A., Tüysüz, O., Kramers, J., 2011. Climate on the southern Black Sea coast during the Holocene: implications from the Sofular Cave record. Quaternary Science Reviews 30(19), 2433-2445.

Hay, B.J., 1988. Sediment accumulation in the central western Black Sea over the past 5100 years. Paleoceanography 3, 491-508.

Hesse, R., Chough, S.K., 1980. The Northwest Atlantic Mid-Ocean Channel of the Labrador Sea: II. Deposition of parallel laminated levee-mud from the viscous sublayer of lowdensity turbidity currents. Sedimentology 27, 697-711. 
Hinderer, M. 2001. Late Quaternary denudation of the Alps, valley and lake fillings and modern river loads. Geodinamica Acta 14, 231-263.

Hiscott, R.N., Aksu, A.E., Mudie, P.J., Marret, F., Abrajano, T., Kaminski, M.A., Evans, J., 囚akiro囚lu, A.I., Yaşar, D., 2007a. A gradual drowning on the southwestern Black Sea shelf: Evidence from a progressive rather than abrupt Holocene reconnection with the eastern Mediterranean Sea through the Marmara Sea Gateway. Quaternary International 167-168, 19-34.

Hiscott, R.N., Aksu, A.E., Mudie, P.J., Kaminski, M.A., Abrajano, T., Yaşar, D., Rochon, A., 2007b. The Marmara Gateway since $\sim 16$ ka: non-catastrophic causes of paleoceanographic events in the Black Sea at $8.4 \mathrm{kyr}$ and $7.15 \mathrm{kyr}$. In: YankoHombach, V., Gilert, A.S., Panin, N., Dolukhanov, P. (Eds.), The Black Sea Flood Question: Changes in Coastline, Climate, and Human Settlement. Springer, Dordrecht, The Netherlands, pp. 89-117.

Ivy-Ochs, S., Kerschner, H., Reuther, A., Preusser, F., Heine, K., Maisch, M., Kubik, P.R., Schlüchter, C., 2008. Chronology of the last glacial cycle in the European Alps. Journal of Quaternary Science 23(6-7), 559-573.

Jones, G.J., Gagnon, A.R., 1994. Radiocarbon chronology of Black Sea sediments. Deep-Sea Research I 41(3), 531-557.

Jorry, S.J., Jégou, I., Emmanuel, L., Silva Jacinto, R., Savoye, B., 2011. Turbiditic levee deposition in response to climate changes: The Var Sedimentary Ridge (Ligurian Sea). Marine Geology 279(1-4), 148-161.

Kasse, C., Bohncke, S.J.P, Vandenberghr, J., Gabris, G., 2010. Fluvial style changes during the last glacial - interglacial transition in the middle Tisza Valley (Hungary). Proceedings of the Geologists' Association 121, 180-194.

Kettner, A.J., and Syvitski, J.P.M., 2009. Fluvial response to environmental perturbations in the Northern Mediterranean since the Last Glacial Maximum. Quaternary Science Reviews 28(23-24), 2386-2397.

Kettner, A.J. and Syvitski, J.P.M., 2008. Predicting Discharge and Sediment Flux of the Po River, Italy since the Last Glacial Maximum. In: P.L. de Boer, G. Postma, C.J. van der Zwan, P.M. Burgess and P. Kukla (Eds.) Analogue and Numerical Forward Modelling of Sedimentary Systems: from Understanding to Prediction. Spec. Publ. Int. Assoc. Sedimentol. 40, 171-189.

Kolla, V., 2007. A review of sinuous channel avulsion pattern in some major deep-sea fans and factors controlling them. Marine and Petroleum Geology 24, 450-469.

Kwiecien, O., Arz, H. W., Lamy, F., Plessen, B., Bahr, A., Haug, G. H., 2009. North Atlantic control on precipitation pattern in the eastern Mediterranean/Black Sea region during the last glacial. Quaternary Research 71(3), 375-384.

Lericolais, G., Bourget, J., Popescu, I., Jermannaud, P., Mulder, T., Jorry, S., Panin, N., 2013. Late Quaternary deep-sea sedimentation in the western Black Sea: New insights from 
recent coring and seismic data in the deep basin. Global and Planetary Change 103, 232-247.

Lericolais, G., Bulois, C., Gillet, H., Guichard, F., 2009. High frequency sea level fluctuations recorded in the Black Sea since the LGM. Global and Planetary Change 66, 65-75.

Lericolais, G., Guichard, F., Morigi, C., Minereau, A., Popescu, I., Radan, S., 2010. A post Younger Dryas Black Sea regression identified from sequence stratigraphy correlated to core analysis and dating. Quaternary International 225, 199-209.

Lericolais, G., Guichard, F., Morigi, C., Popescu, I., Bulois, C., Gillet, H., Ryan, W.B.F., 2011. Assesment of Black Sea water-level fluctuations since the Last Glacial Maximum. The Geological Society of America, Special Paper 473, 1-18.

Lericolais, G., Popescu, I., Guichard, F., Popescu, S.M., 2007. A Black Sea lowstand at 8500 yr B.P. indicated by a relict coastal dune system at a depth of $90 \mathrm{~m}$ below sea level. The Geological Society of America, Special Paper 426, 171-188.

Magyari, E.K., Veres, D., Wennrich, V., Wagner, B., Braun, M., Jakab, G., Karàtson, D., Pàl, Z., Ferenczy, G., St-Onge, G., Rethemeyer, J., Francois, J.-P., von Reumont, F., Schäbitz, F., 2014. Vegetation and environmental responses to climate forcing during the Last Glacial Maximum and deglaciation in the East Carpathians: attenuated response to maximum cooling and increased biomass burning. Quaternary Science Reviews 106, 278-293.

Major, C., Goldstein, S.L., Ryan, W.B.F., Lericolais, G., Piotrowski, A.M., Hajdas, I., 2006. The co-evolution of Black Sea level and composition through the last deglaciation and its paleoclimatic significance. Quaternary Science Reviews 25, 2031-2047.

Major, C., Ryan, W.B.F., Lericolais, G., Hajdas, I., 2002. Constraints on Black Sea outflow to the Sea of Marmara during the last glacial-interglacial transition. Marine Geology 190, 19-34.

Makos, M., Nitychoruk, J. and Zreda, M., 2013. Deglaciation chronology and paleoclimate of the Piecu Stawow Polskich/Roztoki Valley, high Tatra Mountains, Western Carpathians, since the Last Glacial Maximum, inferred from ${ }^{36} \mathrm{Cl}$ exposure dating and glacier-climate modelling. Quaternary International 293, 63-78.

Maslin, M., Knutz, P.C., Ramsay, T., 2006. Millennial-scale sea-level control on avulsion events on the Amazon Fan. Quaternary Science Reviews 25, 3338-3345.

Ménot, G., Bard, E., 2012. A precise search for drastic temperature shifts of the past 40,000 years in southeastern Europe. Paleoceanography 27, PA2210.

Migeon, S., Weber, O., Faugères, J.-C. and Saint-Paul, J., 1999. SCOPIX: A new X-ray imaging system for core analysis. Geo-Marine Letters 18, 251-255.

Mudie, P.J., Yanko-Hombach, V., Kadurin, S., 2014. The Black Sea dating game and Holocene marine transgression. Open Journal of Marine Science 4, 1-7. 
Mulder, T., Syvitski, J.P.M., Migeon, S., Faugères, J.C., Savoye, B., 2003. Marine hyperpycnal flows: initiation, behavior and related deposits. A review. Marine and Petroleum Geology 20(6-8), 861-882.

Nicholas, W.A., Chivas, A.R., Murray-Wallace, C.V., Fink, D., 2011. Prompt transgression and gradual salinisation of the Black Sea during the early Holocene constrained by amino acid racemization and radiocarbon dating. Quaternary Science Reviews 30(2728), 3769-3790.

Niessen, F., Lister, G., Giovanoli, F., 1992. Dust transport and paleoclimate during the Oldest Dryas in Central Europe - implications from varves (Lake Constance). Climate Dynamics 8, 71-81.

Nikishin, A.M., Korotaev, M.V., Ershov, A.V., Brunet, M.-F., 2003. The Black Sea basin: tectonic history and Neogene-Quaternary rapid subsidence modelling. Sedimentary Geology 156(1-4), 149-168.

Panin, N., Panin, S., Herz, N., Noakes, J.E., 1983. Radiocarbon dating of Danube delta deposits. Quaternary Research 19(2), 249-255.

Pilskaln, C.H., Pike, J., 2001. Formation of Holocene sedimentary laminae in the Black Sea and the role of the benthic flocculent layer. Paleoceanography 16, 1-19.

Pirazzoli P. A., 1996. Sea-level changes: the last 20,000 years. Chichester, John Wiley and Sons, $211 \mathrm{p}$.

Popescu, I., Lericolais, G., Panin, N., Wong, H.K., Droz, L., 2001. Late Quaternary channel avulsions on the Danube deep-sea fan, Black Sea. Marine Geology 179, 25-37.

Popescu, I., 2002. Processus sédimentaires récents dans l'éventail profond du Danube (Mer Noire). Unpublished PhD thesis, Université de Bretagne Occidentale - Université de Bucarest, 282 pp. Available on http://archimer.ifremer.fr/doc/2002/these-1206.pdf

Popescu, I., Lericolais, G., Panin, N., Normand, A., Dinu, C., Le Drezen, E., 2004. The Danube submarine canyon (Black Sea): morphology and sedimentary processes. Marine Geology 206, 249-265.

Richter, T.O., Van der Gaast, S., Koster, B., Vaars, A., Gieles, R., De Stigter, H.C., De Haas, H., Van Weering, T.C.E., 2006. The Avaatech XRF Core Scanner: technical description and applications to NE Atlantic sediments. New Techniques in Sediment Core Analysis. Geological Society, London, Special Publications 267, 39-50.

Robinson, A.G., 1997. Regional and petroleum geology of the Black Sea and surrounding region American Association of Petroleum Geologists Memoir 68, 347-368.

Ross, D.A., Degens, E.T., MacIlvaine, J., 1970. Black sea: recent sedimentary history. Science 170, 163-165.

Rothwell, R.G., Hoogakker, B., Thomson, J., Croudace, I.W., Frenz, M., 2006. Turbidite emplacement on the southern Balearic Abyssal Plain (Western Mediterranean Sea) during Marine Isotope Stages 1-3: an application of ITRAX XRF scanning of 
sediment cores to lithostratigraphic analysis. In: R.G. Rothwell (Editor), New Techniques in Sediment Core Analysis. Geological Society, London, Special Publications 267, 79-98.

Ryan, W. B., 2007. Status of the Black Sea flood hypothesis. In Yanko-Hombach, V., Gilbert, A.S., Panin, N., Dolukhanov, P.M. (Editors), The Black Sea Flood Question: Changes in Coastline, Climate, and Human Settlement. Springer Netherlands, 63-88.

Ryan, W.B.F., Major, C.O., Lericolais, G., Goldstein, S.L., 2003. Catastrophic flooding of the Black Sea Annual. Review of Earth and Planetary Science 31, 525-554.

Ryan, W.B.F., Pitman III, W.C., Major, C.O., Shimkus, K., Moskalenko, V., Jones, G., Dimitrov, P., Gorur, N., Sakinc, M., Yuce, H., 1997. An abrupt drowning of the Black Sea shelf. Marine Geology 138, 119-126.

Shumilovskikh, L. S., Arz, H. W., Wegwerth, A., Fleitmann, D., Marret, F., Nowaczyk, N., Tarasov, P., Behling, H., 2013. Vegetation and environmental changes in Northern Anatolia between 134 and 119 ka recorded in Black Sea sediments. Quaternary Research 80(3), 349-360.

Shumilovskikh, L. S., Fleitmann, D., Nowaczyk, N. R., Behling, H., Marret, F., Wegwerth, A., Arz, H. W., 2014. Orbital-and millennial-scale environmental changes between 64 and $20 \mathrm{ka}$ BP recorded in Black Sea sediments. Climate of the Past 10(3), 939-954.

Sidorchuk, A.Y., Panin, A.V., Borisova, O.K., 2011. Surface runoff to the Black Sea from the East European Plain during Last Glacial Maximum-Late Glacial time. The Geological Society of America, Special Paper 473, 1-26.

Sidorchuk, A. Y., Panin, A. V., Borisova, O. K., 2008. Climate-induced changes in surface runoff on the North-Eurasian plains during the late glacial and Holocene. Water Resources 35(4), 386-396.

Soulet, G., Ménot, G., Bayon, G., Rostek, F., Ponzevera, E., Toucanne, S., Lericolais, G., Bard, E., 2013. Abrupt drainage cycles of the Fennoscandian Ice Sheet. Proceedings of the National Academy of Sciences of the United States of America 110(17), 66826687.

Soulet, G., Ménot, G., Garreta, V., Rostek, V., Zaragosi, S., Lericolais, G., Bard, E., 2011 a. Black Sea "Lake" reservoir age evolution since the Last Glacial - Hydrologic and climatic implications. Earth and Planetary Science Letters 308(1-2): 245-258.

Soulet, G., Ménot, G., Lericolais, G., Bard, E., 2011b. A revised calendar age for the last reconnection of the Black Sea to the global ocean. Quaternary Science Reviews 30, 1019-1026.

Stow, D.A.V., Piper, D.J.W., 1984. Deep-water fine-grained sediments: facies model. Finegrained sediments: deep-water processes and facies. Geological Society, Special Publication 15, 611-645. 
Shanmugam, G., Spalding, T.D., Rofheart, D.H., 1993. Process sedimentology and reservoir quality of deep-marine bottom current reworked sands (sandy contourites): an example from the Gulf of Mexico. AAPG Bulletin 77, 1241-1259.

Strechie-Sliwinski, C., 2007. Enregistrements sédimentaires des changements environnementaux récents dans la zone Nord-Ouest de la Mer Noire. Unpublished $\mathrm{PhD}$ thesis, Université Paris-Sud 11 - Université de Bucarest, 445 pp. Available on https://tel.archives-ouvertes.fr/tel-00399227/document.

Toucanne, S., Zaragosi, S., Bourillet, J.F., Naughton, F., Cremer, M., Eynaud, F., Dennielou, B., 2008. Activity of the turbidite levees of the Celtic-Armorican margin (Bay of Biscay) during the last 30,000 years: Imprints of the last European deglaciation and Heinrich events. Marine Geology 247(1-2), 84-103.

Toucanne, S., Zaragosi, S., Bourillet, J.F., Dennielou, B., Jorry, S.J., Jouet, G., Cremer, M., 2012. External controls on turbidite sedimentation on the glacially-influenced Armorican margin (Bay of Biscay, western European margin). Marine Geology 303$306,137-153$.

Wegwerth, A., Dellwig, O., Kaiser, J., Ménot, G., Bard, E., Shumilovskikh, L., Schnetger, B., Kleinhanns, I.C., Wille, M., Arz, H. W., 2014. Meltwater events and the Mediterranean reconnection at the Saalian-Eemian transition in the Black Sea. Earth and Planetary Science Letters 404, 124-135.

Wien, K., Kölling, M., Schulz, H.D., 2007. Age models for the Cape Blanc Debris Flow and the Mauritania Slide Complex in the Atlantic Ocean off NW Africa. Quaternary Science Reviews 26, 2558-2573.

Winguth, C., Wong, H.K., Panin, N., Dinu, C., Georgescu, P., Ungureanu, G., Krugliakov, V.V., Podshuveit, V., 2000. Upper Quaternary water level history and sedimentation in the northwestern Black Sea. Marine Geology 167, 127-146.

Wong, H.K., Panin, N., Dinu, C., Georgescu, P., Rahn, C., 1994. Morphology and postChaudian (Late Pleistocene) evolution of the submarine Danube fan complex. Terra Nova 6, 502-511.

Wong, H.K., Winguth, C., Panin, N., Dinu, C., Wollschläger, G.P., Ungureanu, G., Krugliakov, V.V., Podshuveit, V., 1997, The Danube and Dniepr fans: morphostructure and evolution, Geo-Eco-Marina 2, 77-101.

Yanko-Hombach, V., Gilbert, A.S., Dolukhanov, P., 2007. Controversy over the great flood hypotheses in the Black sea in the light of geological, paleontological and archaeological evidence. Quaternary International 167-168, 91-113.

Yanko-Hombach, V., Mudie, P.J., Kadurin, S., Larchenkov, E., 2014. Holocene marine transgression in the Black sea: New evidence from the northwestern Black Sea shelf. Quaternary International 345, 100-118.

Zaragosi, S., Eynaud, F., Pujol, C., Auffret, G.A., Turon, J.L. and Garlan, T., 2001. Initiation of the European deglaciation as recorded in the northwestern Bay of Biscay slope 
environments (Meriadzek Terrace and Trevelyan Escarpment): a multi-proxy approach. Earth and Planetary Science Letters 188(3-4), 493-507. 


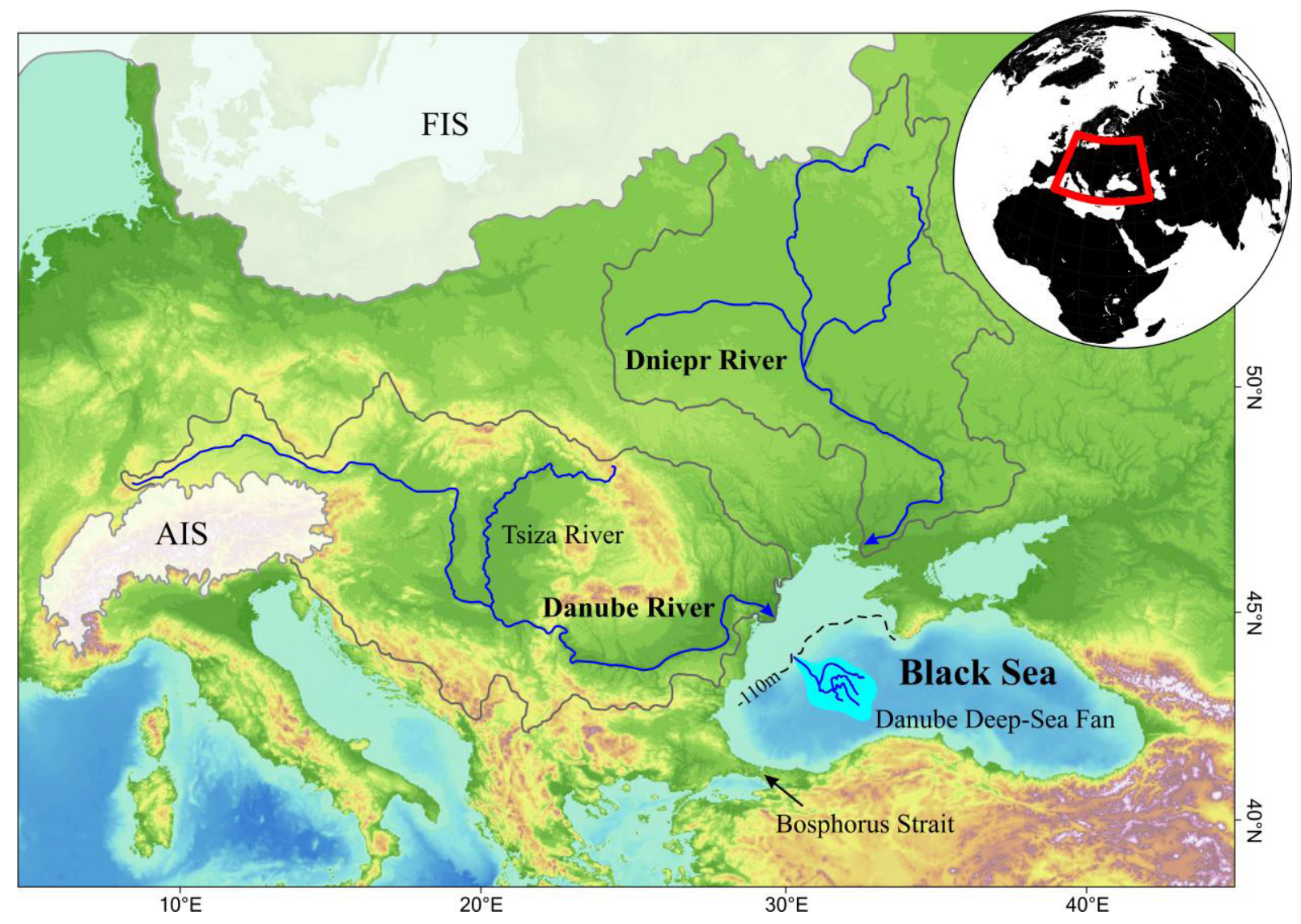

Figure 1 


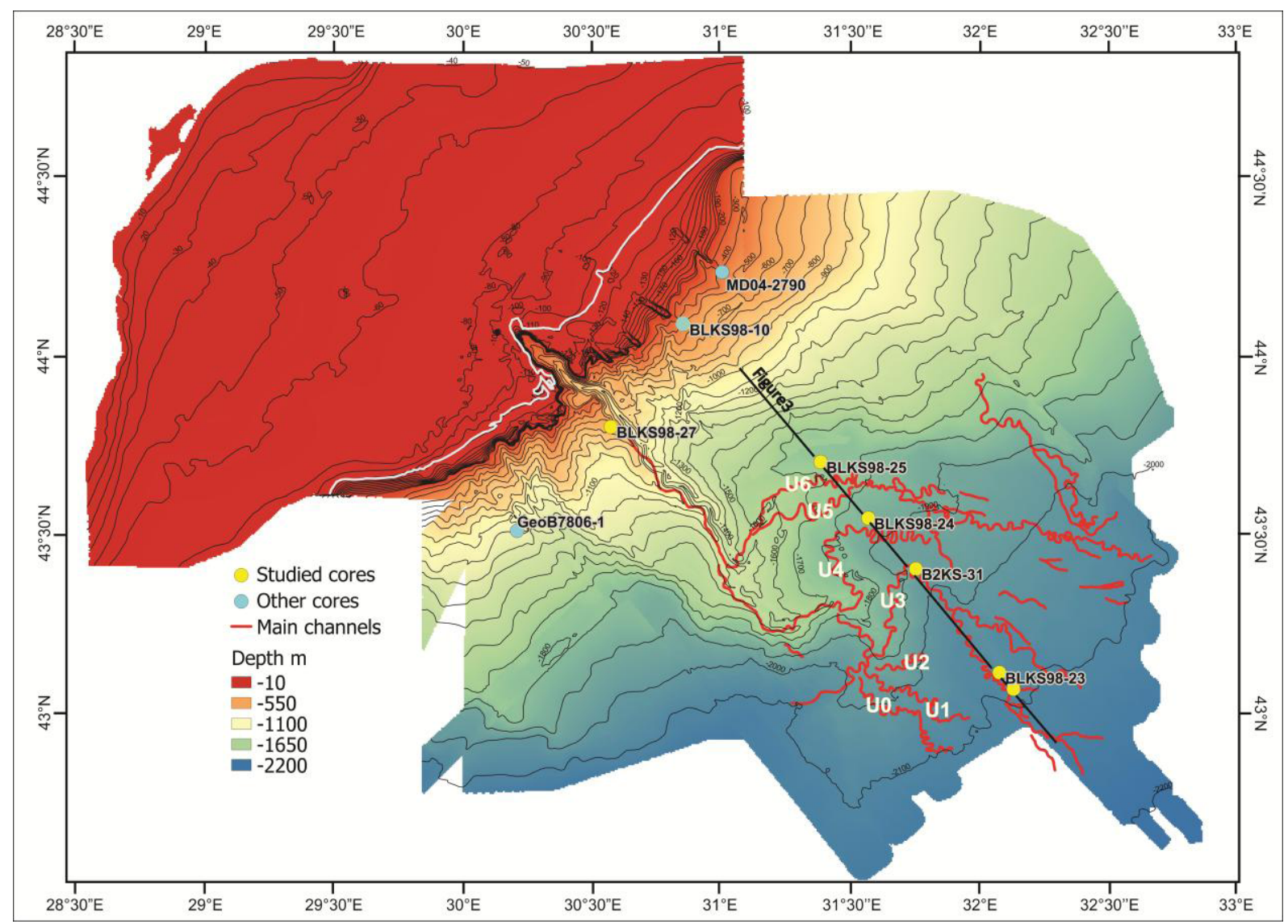

Figure 2 


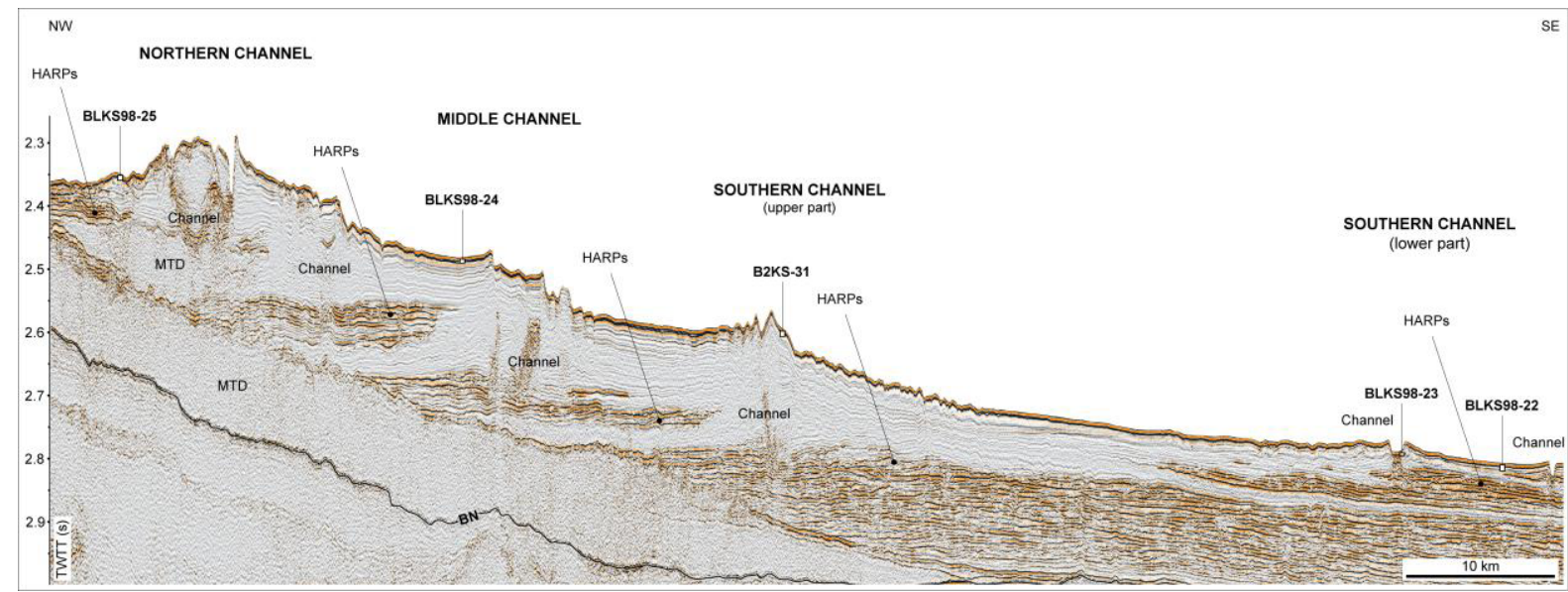

Figure 3 


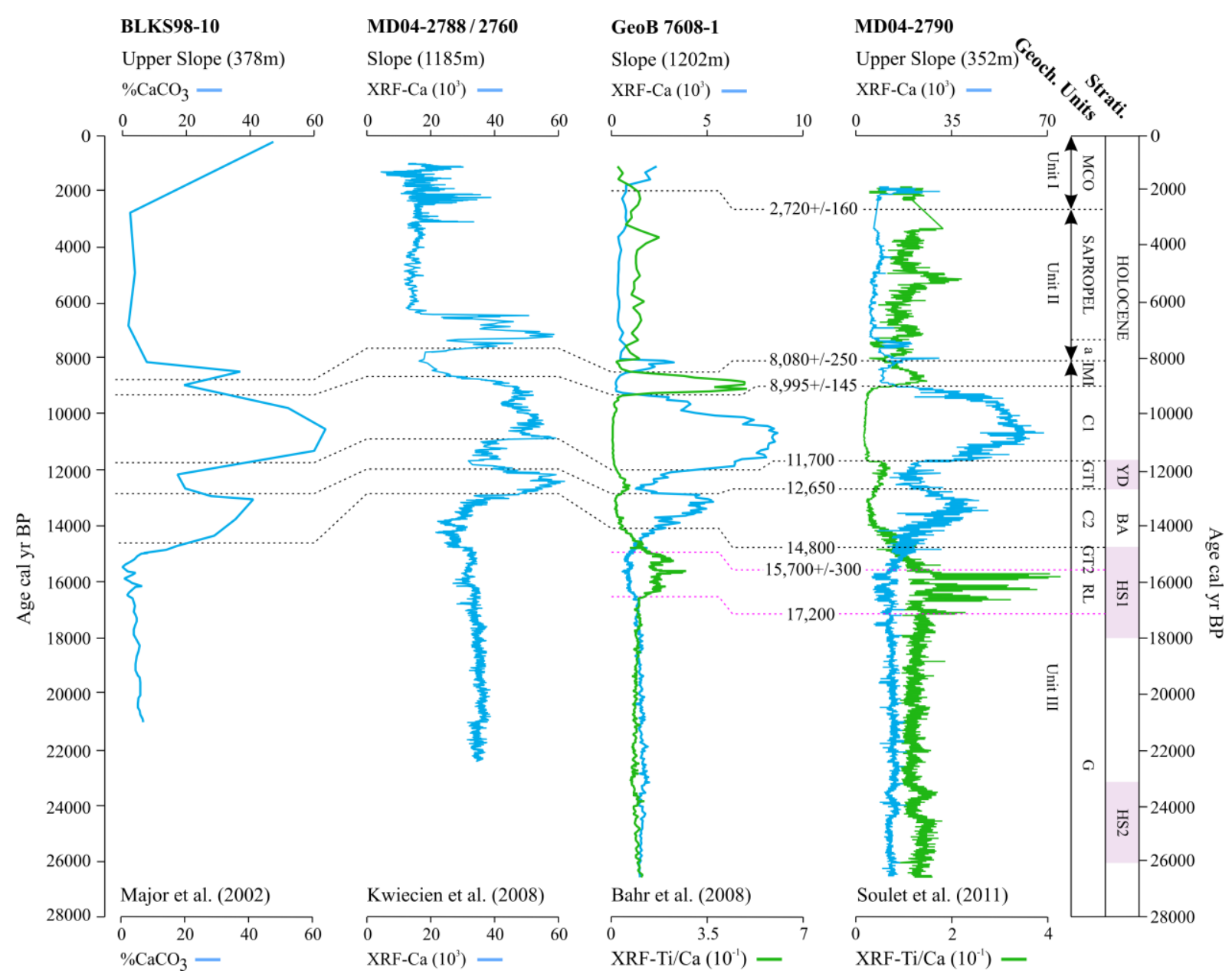

Figure 4 


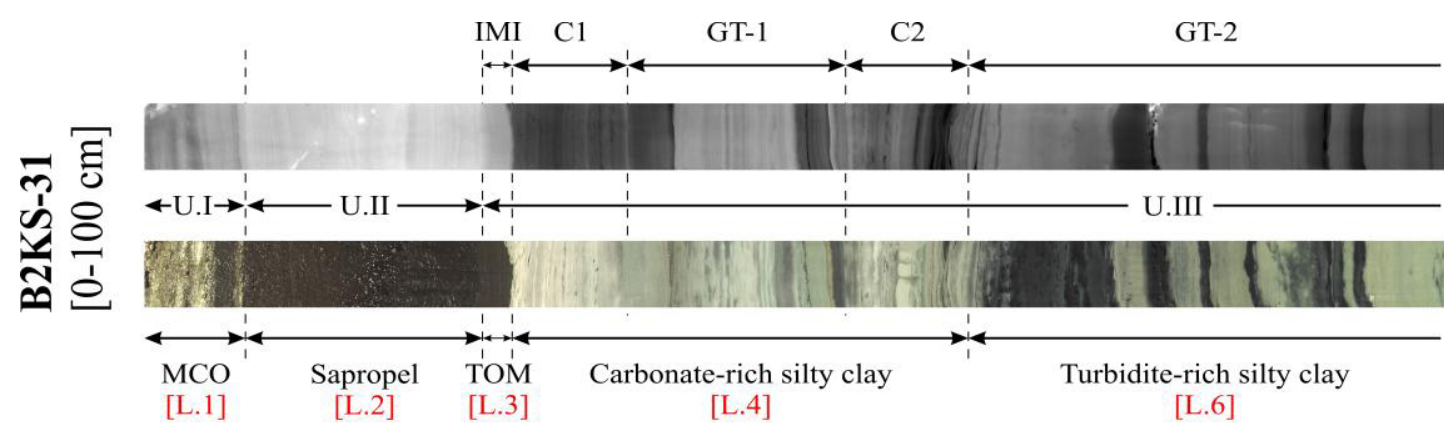

GT-2

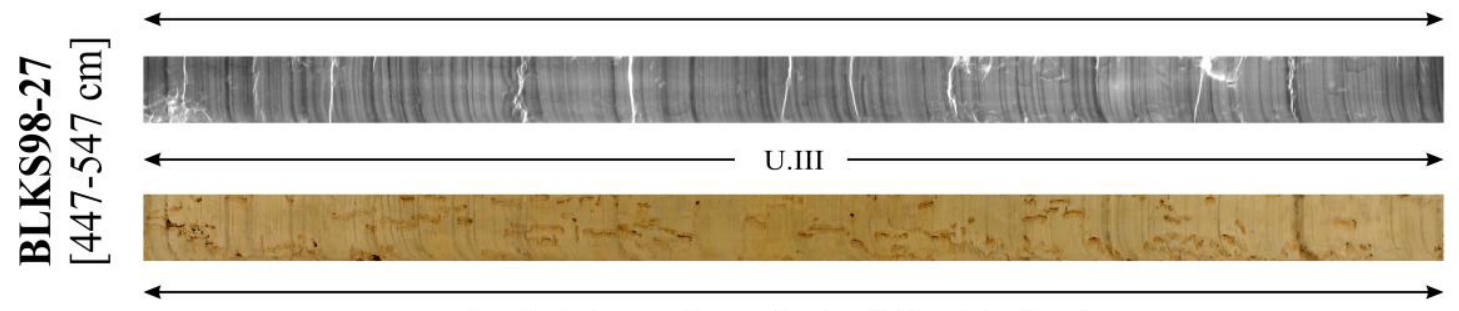

Laminated, very fine-grained turbidite-rich silty clay

[L.6]

RL

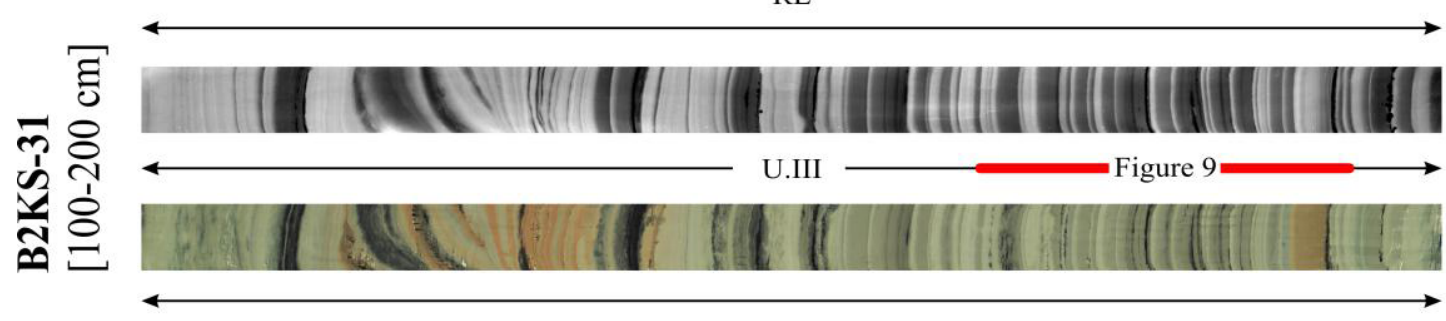

Turbidite-rich silty clay, with some reddish turbidites

[L.6] [L.5]

RL

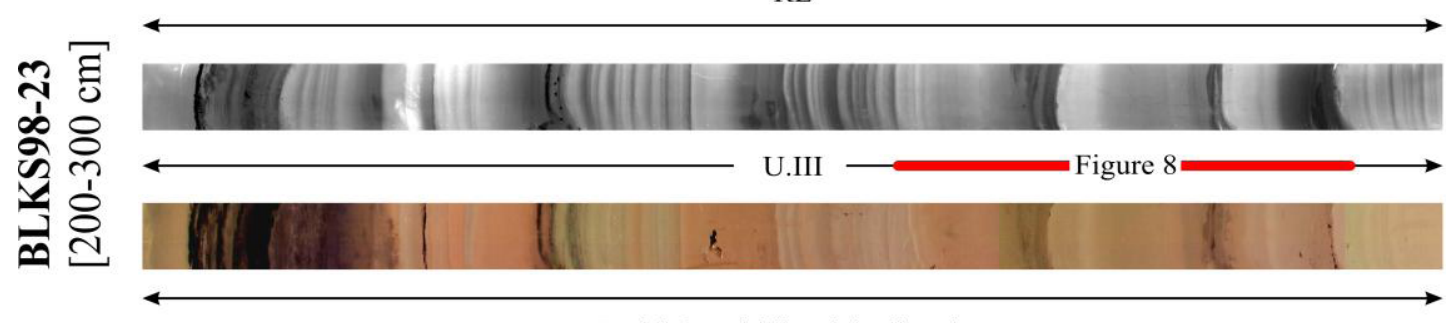

Reddish turbidite-rich silty clay

[L.5]

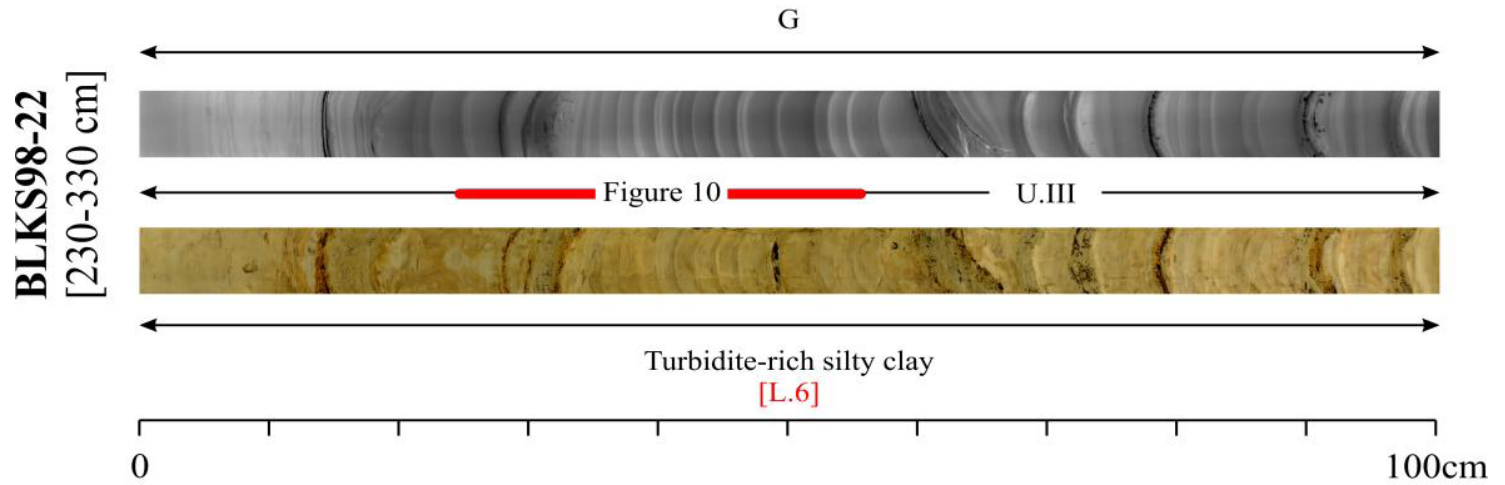

Figure 5 


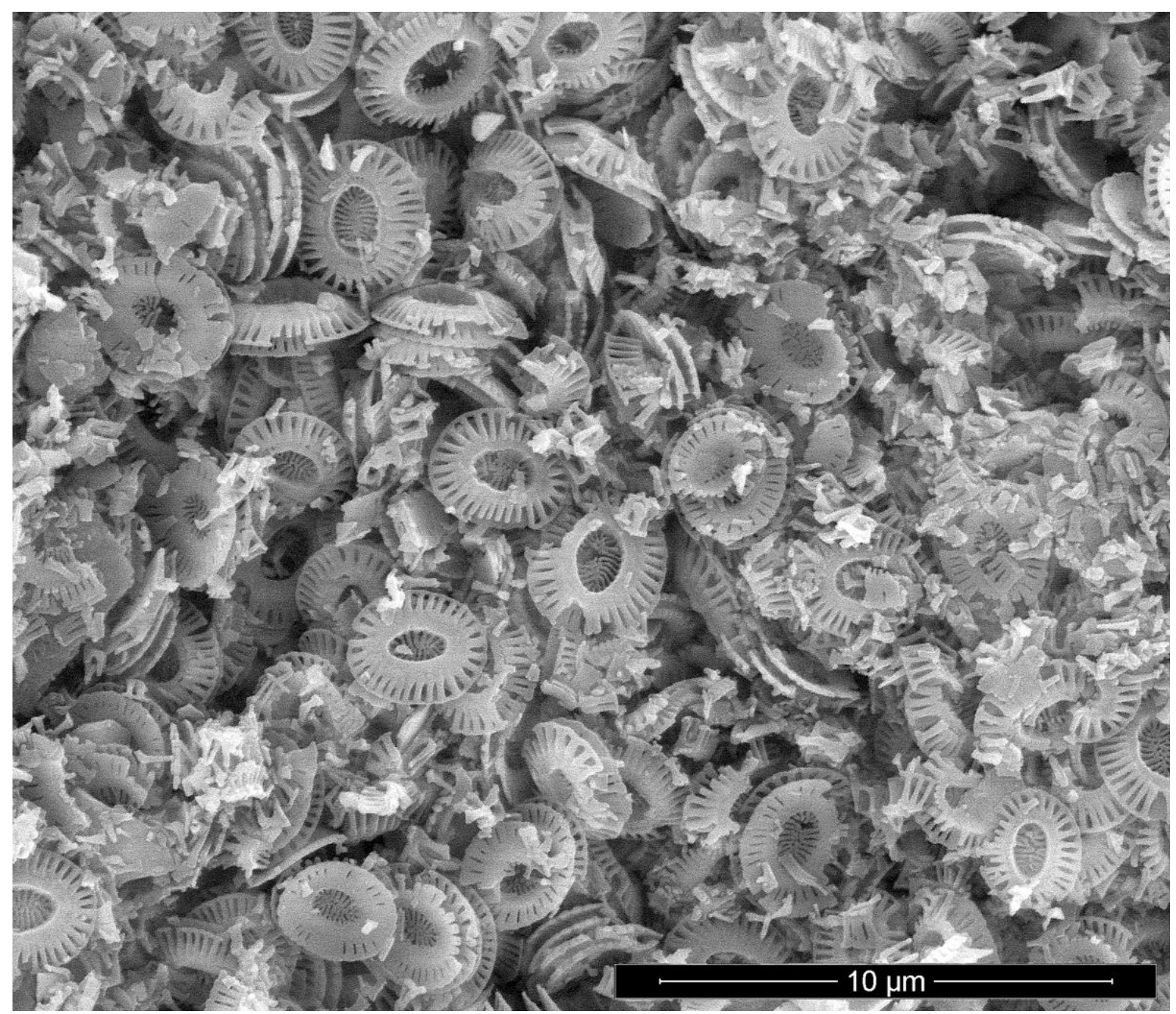

Figure 6 


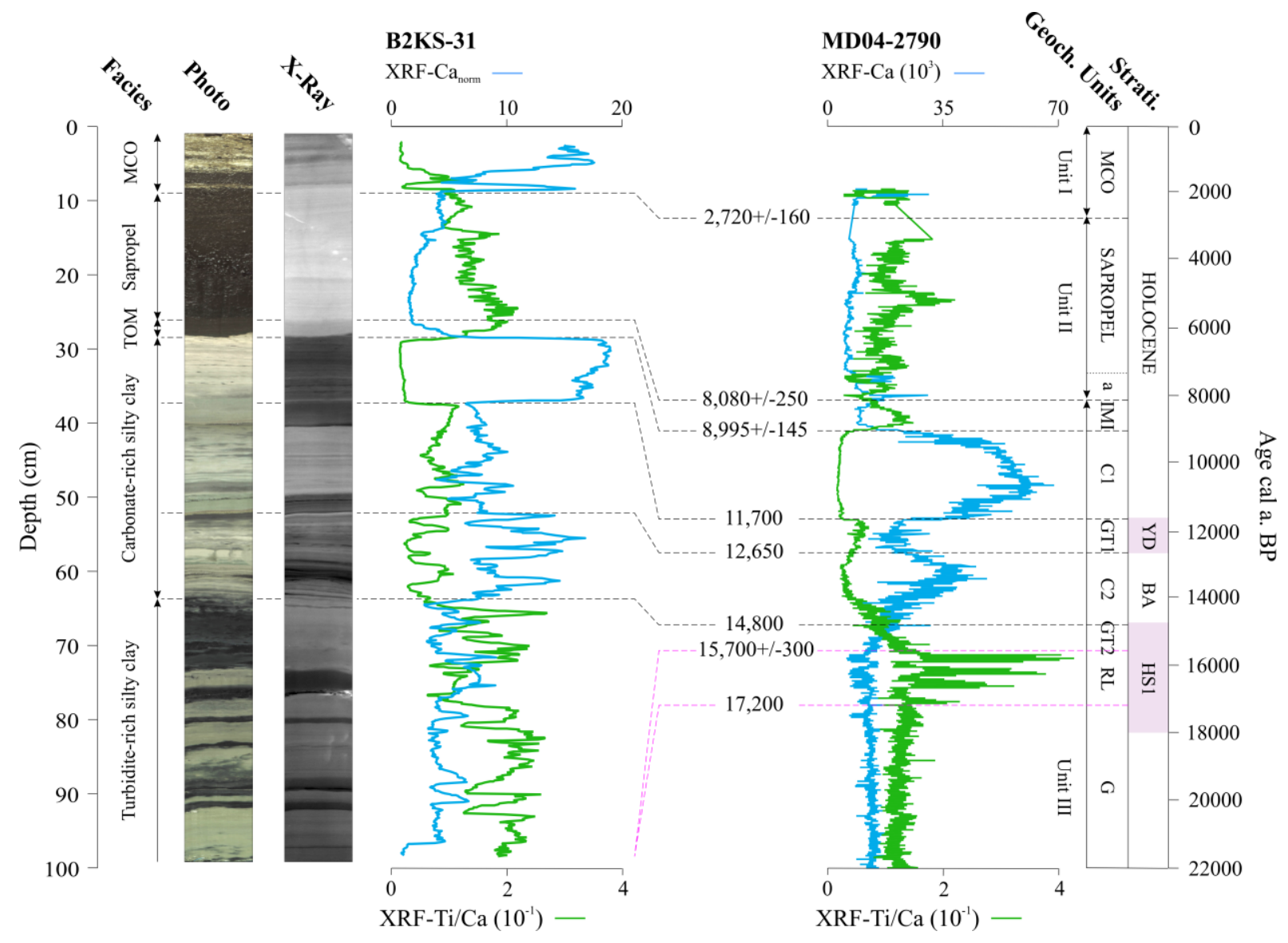

Figure 7 


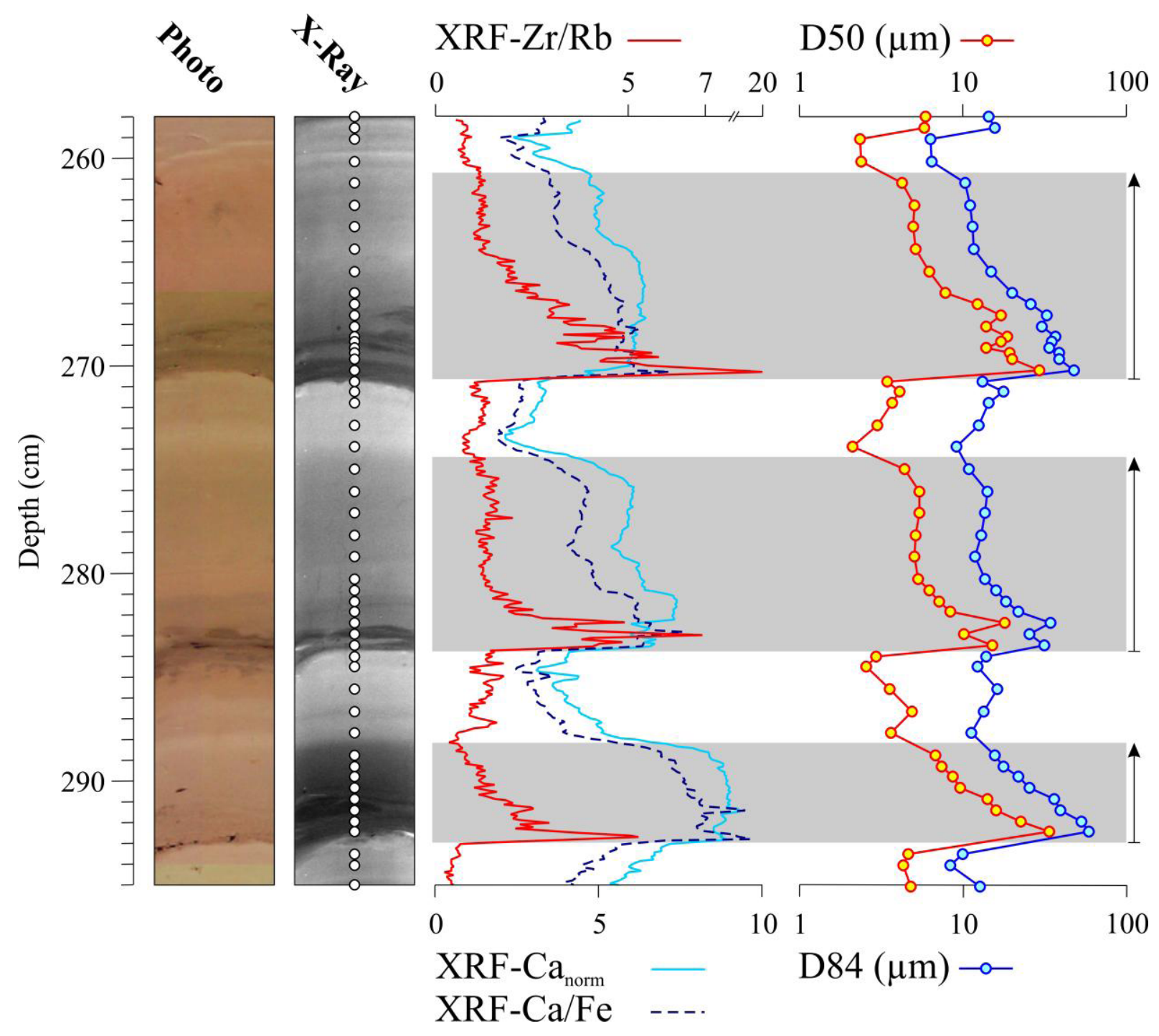

Figure 8 


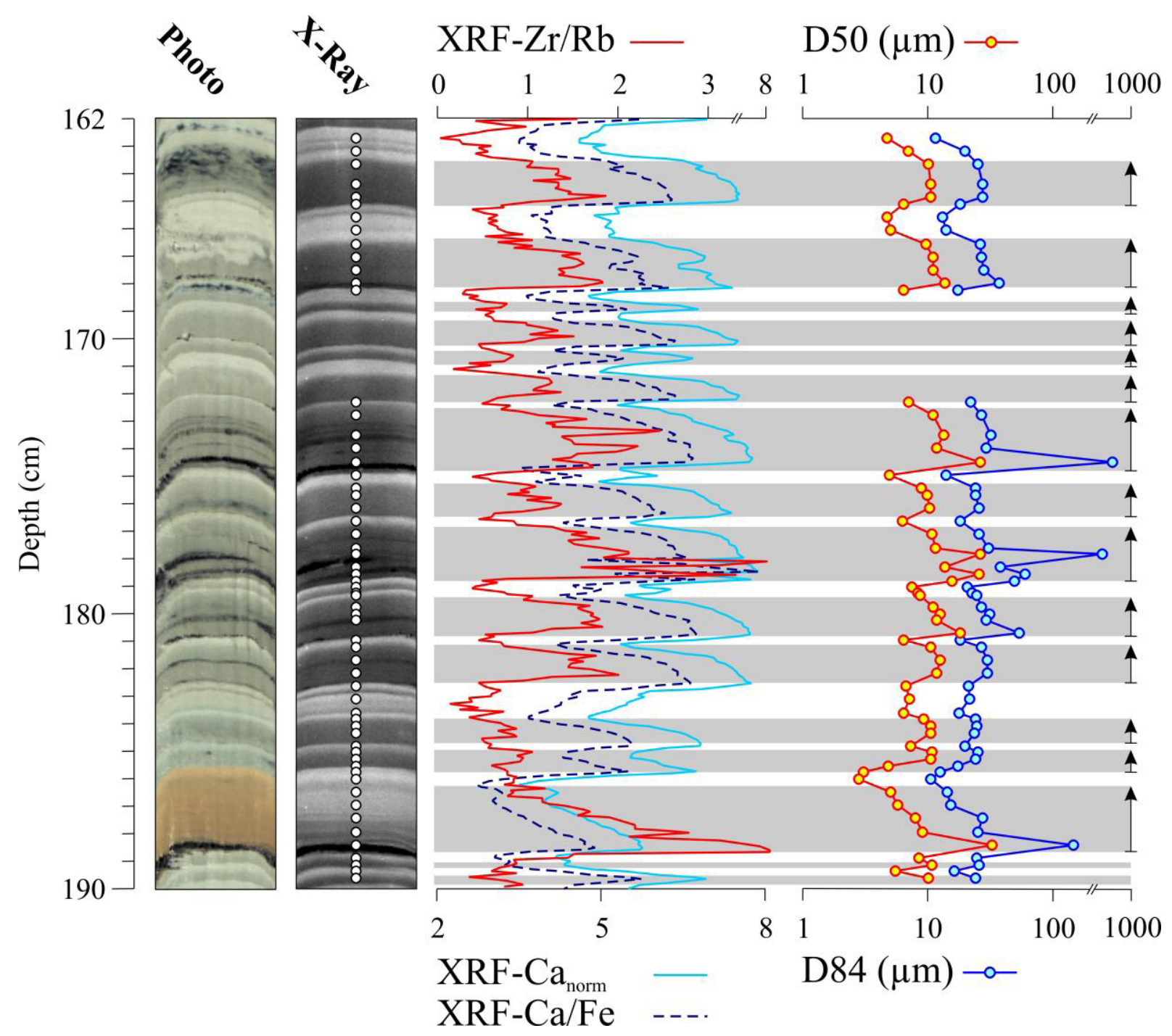

Figure 9 


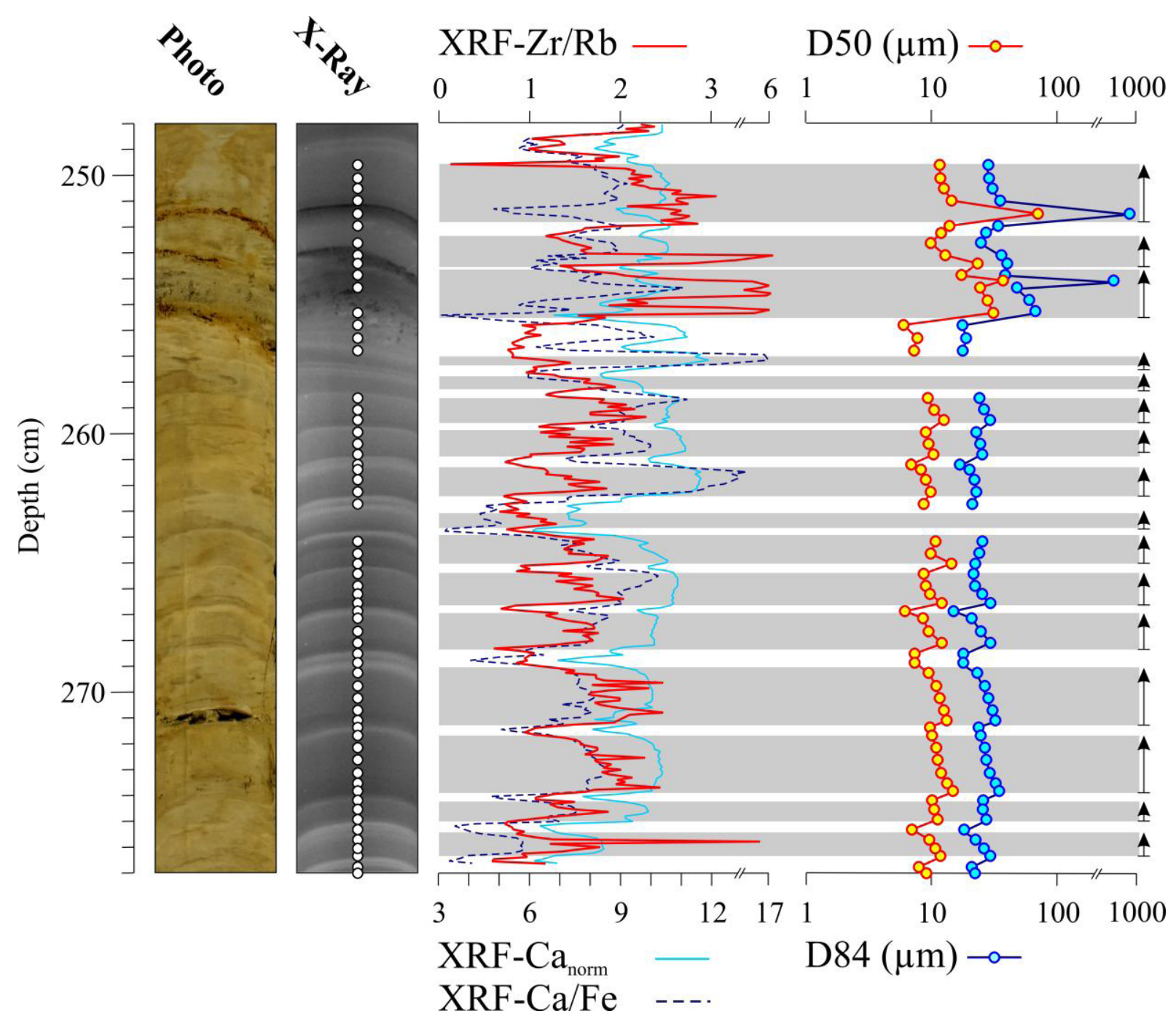

Figure 10 


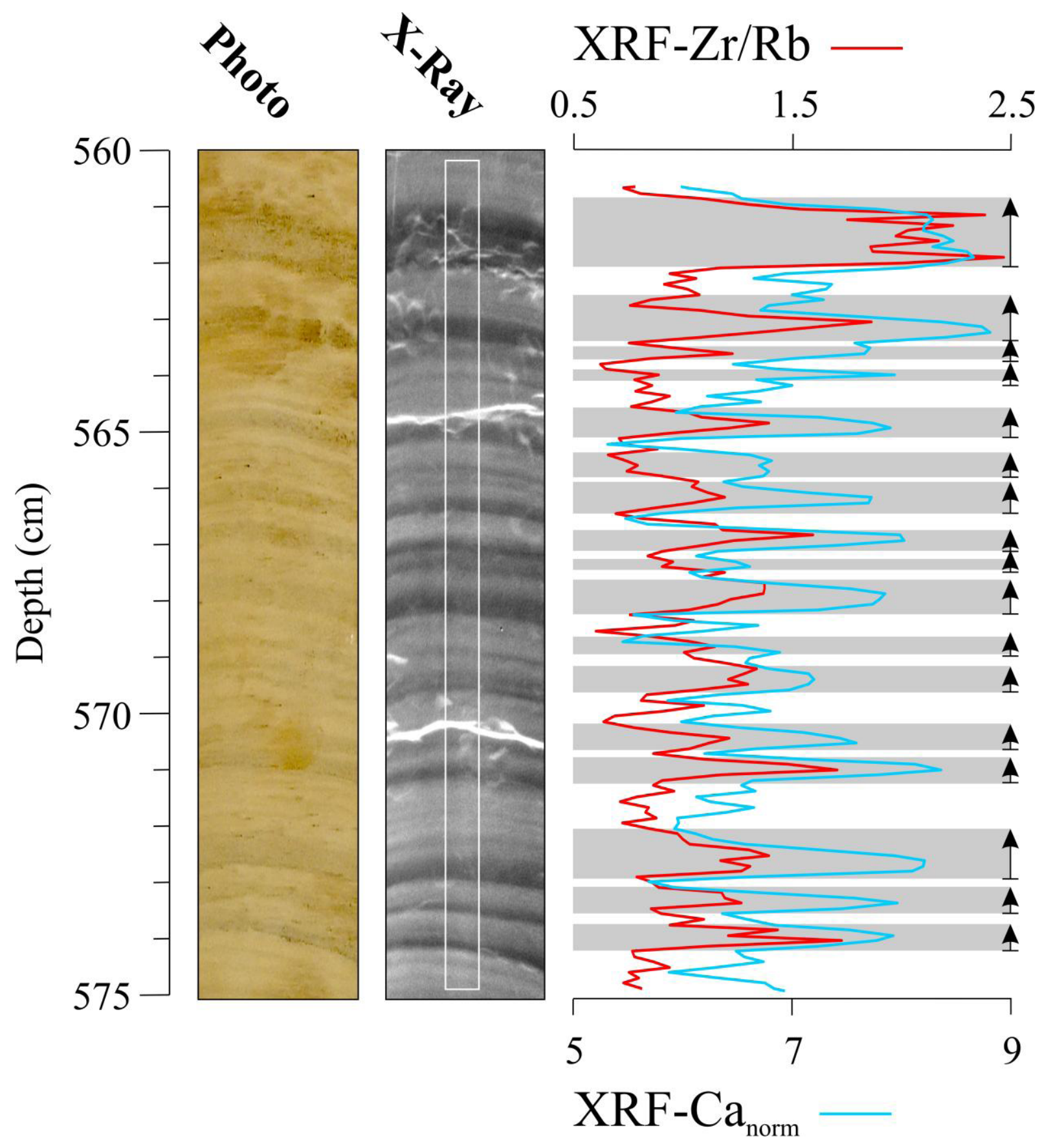

Figure 11 


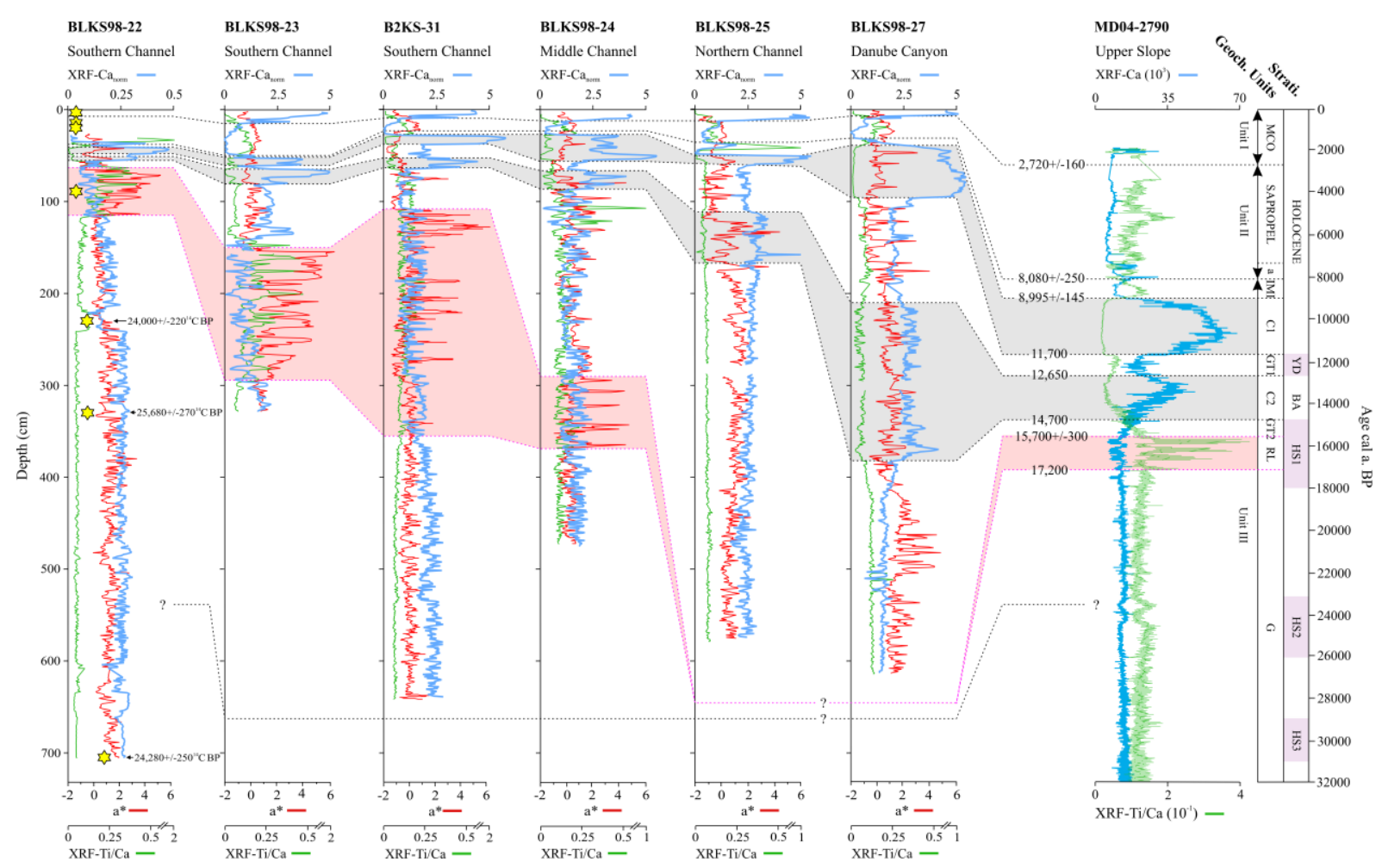

Figure 12 


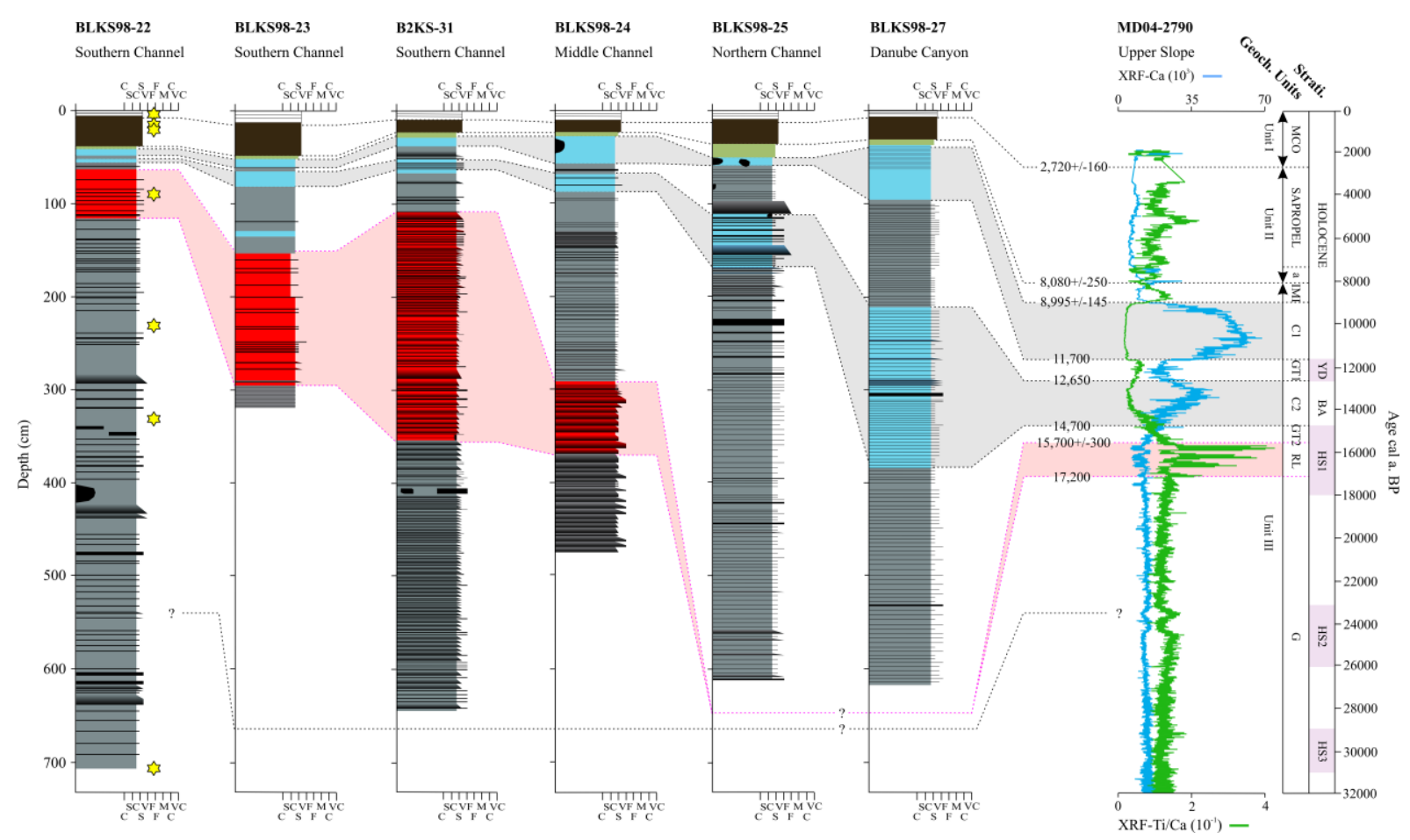

Figure 13 


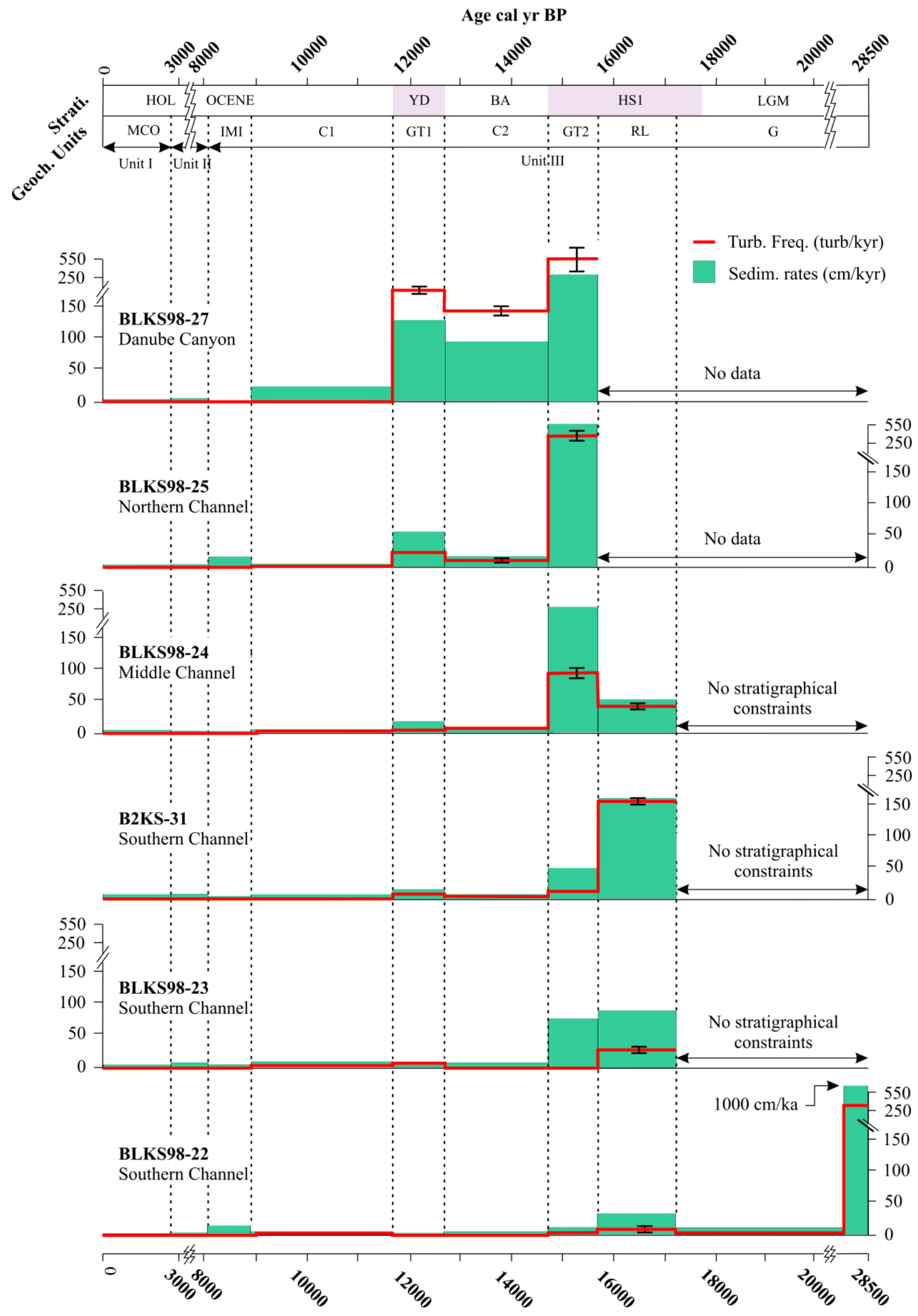

Figure 14 


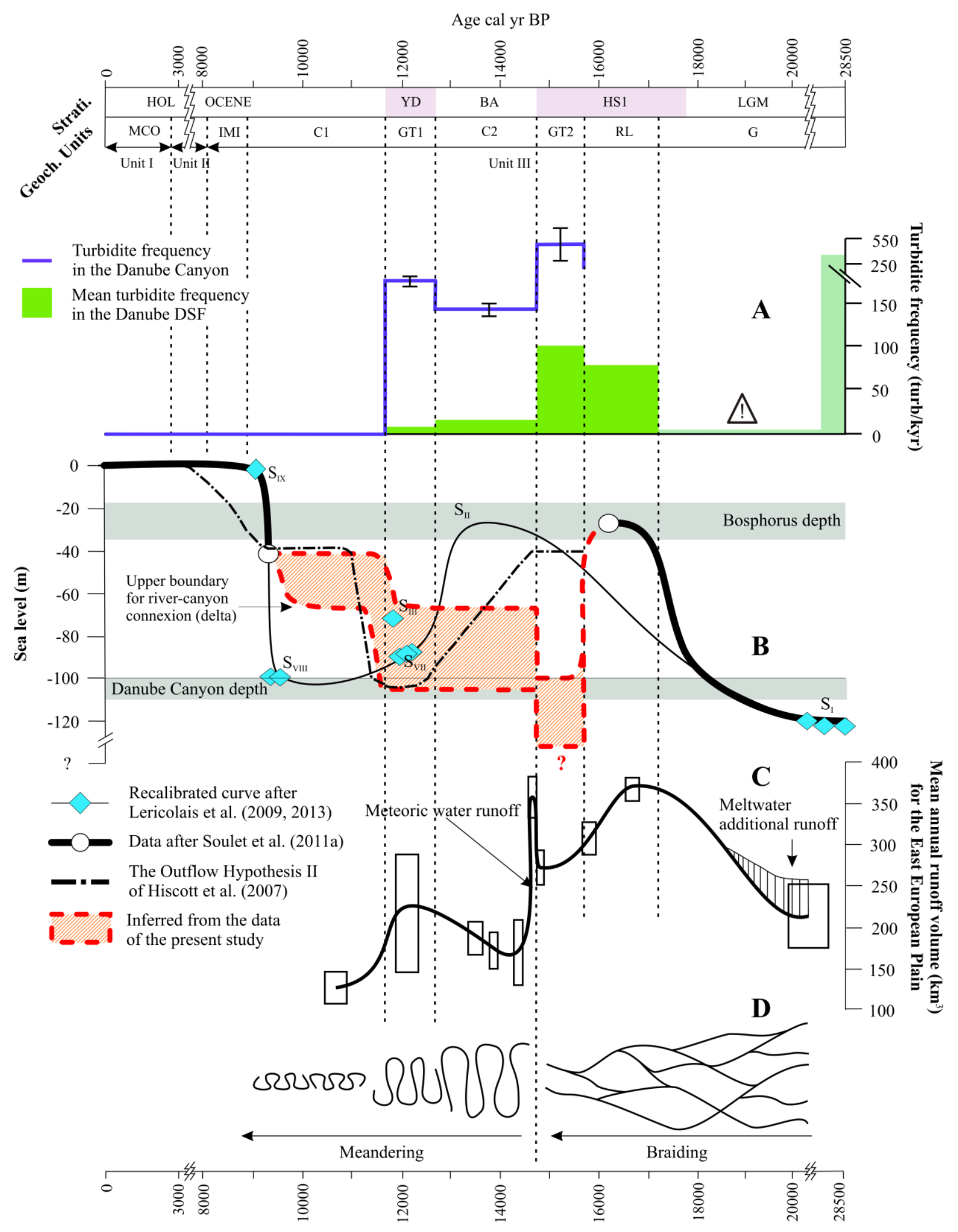

Figure 15 
Table 1

\begin{tabular}{llllll}
\hline Core & Lat. (N) & Long. (E) & \multicolumn{2}{l}{ Depth (mbsl) Length $(\mathbf{c m})$ Physiography } \\
\hline BLKS98-27 & $43^{\circ} 46.78$ & $30^{\circ} 33.65$ & 651 & 617 & Danube Canyon, right flank \\
BLKS98-25 & $43^{\circ} 40.86$ & $31^{\circ} 22.55$ & 1762 & 611 & Northern Channel, left levee (Unit U6) \\
BLKS98-24 & $43^{\circ} 31.33$ & $31^{\circ} 33.67$ & 1862 & 474 & Middle Channel, left levee (Unit U4) \\
B2KS-31 & $43^{\circ} 22.73$ & $31^{\circ} 44.74$ & 1923 & 643 & Southern Channel, left levee (Unit U3) \\
BLKS98-23 & $43^{\circ} 05.07$ & $32^{\circ} 04.23$ & 2090 & 321 & Southern Channel, left levee (Unit U3) \\
BLKS98-22 & $43^{\circ} 02.27$ & $32^{\circ} 07.49$ & 2100 & 712 & Southern Channel, right levee (Unit U3) \\
\hline
\end{tabular}


Table 2

\begin{tabular}{|c|c|c|c|c|c|c|c|c|}
\hline \multirow{2}{*}{$\begin{array}{c}\text { Stratigra } \\
\text { phic } \\
\text { Transitio } \\
\text { n }\end{array}$} & \multirow{2}{*}{$\begin{array}{l}\text { Age (cal } \\
\text { yr BP) } \\
\text { MD04- } \\
2790\end{array}$} & \multicolumn{6}{|c|}{ Depth (cm) } & \multirow{2}{*}{$\begin{array}{c}\text { Identification } \\
\text { of } \\
\text { stratigraphic } \\
\text { markers }\end{array}$} \\
\hline & & BLKS98-22 & $\begin{array}{c}\text { BLKS98- } \\
23 \\
\end{array}$ & B2KS-31 & $\begin{array}{c}\text { BLKS9 } \\
8-24 \\
\end{array}$ & $\begin{array}{c}\text { BLKS98- } \\
25 \\
\end{array}$ & BLKS98-27 & \\
\hline $\begin{array}{l}\text { MCO / } \\
\text { Sapropel }\end{array}$ & $\begin{array}{c}2,720 \pm \\
160\end{array}$ & 5 & 13 & 9 & 12 & 12 & 9 & $\begin{array}{c}\text { visual descr. + } \\
\text { decrease of } \\
\text { XRF-Ca }\end{array}$ \\
\hline $\begin{array}{l}\text { Sapropel } \\
\text { / IMI }\end{array}$ & $\begin{array}{c}8,080 \pm \\
250\end{array}$ & 36 & 47 & 26 & 24 & 38 & 35 & $\begin{array}{c}\text { visual } \\
\text { description }\end{array}$ \\
\hline IMI / C1 & $\begin{array}{c}8,995 \pm \\
145\end{array}$ & 41 & 51 & 28 & 28 & 51 & 40 & $\begin{array}{c}\text { significant } \\
\text { increase in } \\
\text { XRF-Ca }\end{array}$ \\
\hline C1 / GT1 & 11,700 & 48 & 59 & 36 & 55 & 61 & 96 & $\begin{array}{l}\text { significant } \\
\text { decrease in } \\
\text { XRF-Ca }\end{array}$ \\
\hline GT1 / C2 & 12,650 & 51 & 63 & 52 & 66 & 116 & 210 & $\begin{array}{c}\text { significant } \\
\text { increase in } \\
\text { XRF-Ca }\end{array}$ \\
\hline C2 / GT2 & 14,800 & 56 & 78 & 64 & 86 & 170 & 385 & $\begin{array}{c}\text { significant } \\
\text { decrease in } \\
\text { XRF-Ca }\end{array}$ \\
\hline GT2 / RL & $\begin{array}{l}15,700 \pm \\
300\end{array}$ & 65 & 155 & 110 & 290 & - & - & $\begin{array}{c}\text { visual } \\
\text { description + } \\
\text { increase in } a^{*}\end{array}$ \\
\hline $\mathrm{RL} / \mathrm{G}$ & 17,200 & 117 & 287 & 360 & 375 & - & - & $\begin{array}{c}\text { visual } \\
\text { description + } \\
\text { decrease in } a^{*}\end{array}$ \\
\hline
\end{tabular}


Table 3

\begin{tabular}{|c|c|c|c|c|c|c|c|}
\hline Core label & Depth $(\mathrm{cm})$ & Unit & Lab. Number & ${ }^{14} \mathrm{C}$ age (yr B & error (1区) & Sample Material Typ & $\begin{array}{c}\text { Age (cal } \\
\text { yr BP) } \\
\text { median } \\
\text { probability }\end{array}$ \\
\hline BLKS98-22 & 4 & 1 & LSCE GifA-101540 & 2600 & 60 & organic matter & 1979 \\
\hline BLKS98-22 & 23 & II & LSCE GifA-101541 & 7000 & 80 & organic matter & 7345 \\
\hline BLKS98-22 & 26 & ॥ & LSCE GifA-101542 & 7600 & 90 & organic matter & 7848 \\
\hline BLKS98-22 & 90 & III & LSCE GifA-102101 & 18420 & 160 & organic matter & $21597^{*}$ \\
\hline BLKS98-22 & 229 & III & LSCE GifA-101543 & 24000 & 220 & organic matter & $27606^{*}$ \\
\hline BLKS98-22 & 328 & III & LSCE GifA-101544 & 25680 & 270 & organic matter & $29153^{*}$ \\
\hline BLKS98-22 & 712 & III & CAMS-93534 & 24280 & 250 & organic matter & $27815^{*}$ \\
\hline
\end{tabular}


Research highlights

$>$ We propose the first high-resolution stratigraphic framework for the Danube Deep-Sea Fan

> Significant shifts in the location of turbidite depocenter since the Last Glacial Maximum

$>$ The turbidite activity in the Danube Deep-Sea Fan abruptly stopped ca. 11,700 yr BP

$>$ Our results give new insights into Black Sea water-level fluctuations 